\title{
Impact of Green Fiscal Policy on the Investment Efficiency of Renewable Energy Enterprises in China
}

\section{Zhaosu Meng ( $\square$ zhaosu.meng@ouc.edu.cn )}

Ocean University of China - Laoshan Campus: Ocean University of China https://orcid.org/0000-00023291-6975

\section{Huike SUN}

Ocean University of China - Laoshan Campus: Ocean University of China

\section{Xiaotong LIU}

Ocean University of China - Laoshan Campus: Ocean University of China

\section{Research Article}

Keywords: Renewable energy enterprise, Green fiscal policy, Corporate investment efficiency, Richardson model, Fixed-effect panel model

Posted Date: January 31st, 2022

DOI: https://doi.org/10.21203/rs.3.rs-1266981/v1

License: (c) (1) This work is licensed under a Creative Commons Attribution 4.0 International License. Read Full License 


\section{Abstract}

This study focuses on the investment efficiency of renewable energy enterprises and how they respond to government green fiscal policies. It complements previous research that only examines corporate investment efficiency from government subsidies or tax incentives. Moreover, we extend the impact of green fiscal policies on the investment inefficiency of renewable energy enterprises from the perspective of property heterogeneity. We choose financial data of 158 renewable energy enterprises for both state-owned (SOEs) and private (Non-SOEs) listed on the Shanghai and Shenzhen Stock Exchange from 2010-2018 and use the Richardson model to measure the investment efficiency. The fixed-effect panel model is applied to explore the impact of green fiscal policies on the investment efficiency of renewable energy enterprises. The results show that, in general, green financial subsidies aggravate over-investment, especially for SOEs, while green tax incentives alleviate under-investment considerably, especially for Non-SOEs. We also find inefficient investment pervasive in China, among which the over-investment problem more serious than underinvestment. But for the Non-SOEs, under-investment is more predominant. Finally, we propose that government subsidies for SOEs should be constrained and supervised, while more flexible tax incentives for Non-SOEs should be advocated.

\section{Introduction}

Guided by the conviction that lucid waters and lush mountains are invaluable assets, the Chinese government has put much effort into environmental improvement and advocated for a green and low-carbon lifestyle. At United Nations General Assembly (UNGA) in September 2020, China announced a climate pledge to peak carbon dioxide emissions before 2030 and achieve carbon neutrality before 2060 . To meet these commitments, the Chinese government has adopted various green fiscal policies to support the renewable energy market. Among which, green financial subsidies and green tax incentives are the primary tools to influence the renewable energy industry, improving their investment efficiency.

However, what is the investment efficiency of Chinese renewable energy firms as China enters the "New Normal" period? Can green fiscal measures, such as financial subsidies and tax incentives, help renewable energy companies invest more efficiently? Will the consequences differ depending on the type of policy been used and the nature of the renewable energy enterprises' property rights? These issues have not been revealed extensively from previous studies. Undoubtedly, enterprises with property heterogeneity, response differently to the fiscal policies, thus influence their investment efficiency. Therefore, it is necessary to combine the factors with conventional factors to accurately explore the impact of different fiscal policies on renewable enterprises.

This paper fills such a gap by investigating the investment efficiency of renewable energy enterprises and discusses their response to different government green fiscal policies. We choose financial data of 158 renewable energy enterprises for both state-owned (SOEs) and private (Non-SOEs) listed on the Shanghai and Shenzhen Stock Exchange from 2010-2018. We use the Richardson model to measure the investment efficiency. The fixed-effect panel model is applied to explore the impact of green fiscal policies on the investment efficiency of renewable energy enterprises. Therefore, this paper can be considered as an 
extension of the existing studies and may be helpful to more comprehensively uncover the impact of green fiscal policy on the performance of renewable energy enterprises.

The renewable energy market in China has been thriving with fiscal incentives, rigorous environmental regulation, and investment consciousness improvement. In 2020, China has topped the world in renewable energy production and utilization. By 2020, the national renewable energy power production reached 2214.8 billion $\mathrm{kWh}$, increased about $8.4 \%$. The ratio of renewable energy power production to the total power production has reached $29.5 \%$ (Fig. 1), among which, hydropower accounts for a large proportion of renewable energy generation, and solar energy and biomass energy market are emerging.

Meanwhile, China's renewable energy utilization has increased dramatically. In 2020, the scale of renewable energy utilization in China reached 680 million tonnes of standard coal, and the share of renewable energy in primary energy consumption has increased to $15.7 \%$ (Fig. 2). These achievements have provided a solid guarantee for reducing pollution and carbon emissions and consolidating the foundation for eco-civilization.

Various fiscal measures are used to encourage and stimulate the development of renewable enterprises in China. Tax preference is a kind of ex-post incentive. By offering preferential tax policies for renewable energy enterprises conducive to environmental protection, the operating costs of the enterprises are dropped and the insufficient investment is eased. The current preferential tax policies for the renewable energy industry mainly focus on value-added tax, income tax, and business tax. Financial subsidies are more of an ex-ante incentive. The primary purpose of financial subsidies is to promote energy conservation and emission reduction, ensure environmental carrying capacity, and achieve optimal allocation and rational use of resources. For renewable energy enterprises, subsidies provide considerable cash flow, which can attract banks and other investors to increase the inflow of external funds. Government subsidies in the renewable energy industry have increased yearly in the recent ten years, but the total financial subsidies for renewable energy have not met the demand yet (Fig. 3).

The government subsidies and tax incentives received by renewable energy enterprises vary according to the nature of property rights. Although there is a growing number of listed private enterprises (Non-SOEs) in China and the private sector has fueled most of China's economic growth in the last two decades (Allen et al., 2005), listed SOEs still rule the capital market in China. Moreover, recent years have observed growing government policies give preferentiality to the state sector. In industries such as energy, SOEs are more in a dominant position. Thus, SOEs get more government subsidies than non-SOEs. The government encourages the implementation of tax incentives for renewable energy that is conducive to environmental protection. Non-SOEs tend to be more sensitive to these tax preferential policies as they have relatively narrow financial channels and more capital constraints. These tax refunds give company more freedom regarding to R\&D and investment.

The rest of the paper is structured as follows. Section 2 reviews previous literature and proposes research hypotheses. Section 3 deals with the basic model, variables, and data. Section 4 measures the investment efficiency of renewable energy enterprises using the Richardson model. We then applied a fixed-effect model to measure and compare the impact of different green fiscal policies on the investment efficiency of renewable energy enterprises. Furthermore, we compare the impact of government subsidy and tax incentive 
on renewable enterprises with different property rights. Section 5 presents our conclusions and implications for policymakers.

\section{Literature Review And Hypotheses Related literature}

There are many factors that affect the investment efficiency of enterprises, such as free cash flow, agency cost, and corporate size. Some factors are internal. Jensen (1986) found that senior managers tend to do blind investment to maximize benefits when free cash flow is sufficient, which easily leads to excessive investment. Morgado (2003) revealed that when ownership concentration was too high, executives could make blind investments by investing in high-risk projects, thereby reducing the investment efficiency of enterprises. Studies also show a negative correlation between the asset-liability ratio and investment efficiency (Aivazian 2005). Aggarwal and Samwick (2006) pointed out that the ownership structure reduces the investment efficiency by aggravating over-investment because the interest conflict leads agents to invest blindly to maximize their profit. Corporate size has a specific impact on the efficiency of enterprise investment. The larger the enterprise scale, the more likely it is to produce an excessive investment (Iuliana 2008). Biddle et al. (2009) revealed that high-quality financial statements help corporate executives make investment decisions more accurately, thereby effectively improving investment efficiency. The existence of moral hazard problems makes the free cash flow not properly used and aggravates the over-investment of enterprises (Xiao 2010). Billett (2011) believed that when the corporate governance structure is reasonable, enterprises can better control investment projects, to improve the investment efficiency of enterprises. O'Toole et al. (2016) found that when the corporate governance structure and scale are different, there are apparent differences in investment efficiency. Wang et al. (2018) provided robust evidence that credit distortion adversely affects corporate investment efficiency, while better managerial forecast ability mitigates this negative effect. Francisco et al. (2020) found that debt has a particular impact on investment efficiency, and the impact of debt on investment efficiency is mainly achieved through over-investment rather than under-investment. Mohammed et al. (2020) found a positive correlation between corporate tax avoidance activities and low investment efficiency. Yu et al. (2021) found that government information disclosure significantly improves enterprise investment efficiency, and this effect is stronger for Non-SOEs and enterprises in regulated industries.

In addition to internal factors, policy factors also affect the investment efficiency of renewable energy enterprises, such as tax policies, economic cycle, monetary and fiscal policy. Fan et al. (2006) found that preferential tax policies reduced the research and investment costs, thus increasing enterprises' investment efficiency. Lokshin et al. (2011) found that tax incentives can improve the enthusiasm of enterprises in the Netherlands, thereby improving their innovation ability and investment efficiency. Fakhfakh et al. (2012) pointed out that business cycle and monetary policies may cause uncertainty of the business environment and affect the investment efficiency of enterprises. Karim et al. (2013) found that monetary policy can affect the investment efficiency of enterprises by affecting the cost of capital use. Hottenrott and Lopes-Bento (2014) pointed out that government subsidies can improve the level of R\&D expenditure, thereby improving the enterprises' innovation ability and R\&D ability, thus effectively improving the investment efficiency. 
Zulkhibri (2015) revealed that monetary policy could affect the enterprises' cash flow obtained through credit channels and bank loan channels, which affects the investment efficiency. Gulen (2016) believed that there was uncertainty in implementing economic policies, which inhibits corporate investment behavior and reduces investment efficiency. Liang et al. (2019) used a panel model to study corporate investment efficiency and found that developed regions can use government subsidies more efficiently than developing regions. Kwon et al. (2020) revealed that innovations in monetary policy influence corporate investment inefficiency significantly. Liu et al. (2021) found that tax incentive policies will effectively improve the economic benefits of enterprises. Peng et al. (2022) revealed that the green credit policy has significantly reduced the short-term and long-term debt financing of heavily polluting enterprises.

Some scholars have focused on the impact of green financial subsidies and green tax incentives on the investment efficiency of renewable energy enterprises. Butler et al. (2008) found significant differences in enterprises' investment efficiency in the impact of different types of government subsidies, such as financial subsidies, tax incentives, or interest rate loans. Tax subsidies can stimulate the enthusiasm of enterprises and improve corporate performance more than financial subsidies. Singarao and Singh (2014) pointed out that the green tax policies formulated by the United States mainly include quota systems, production tax credits, and so on. These green tax policies can promote renewable energy enterprises. Zhang et al. (2014) found that government subsidies significantly improved the financial performance of wind energy manufacturing companies and increased investment efficiency. Comello et al. (2016) found that investment tax credits in the United States contribute to the rapid development of solar photovoltaic and fuel cell industries. Nie et al. (2016) found that government subsidies increased the output of renewable energy enterprises, thereby improving enterprises' investment efficiency. Mundaca (2017) found that reducing renewable energy subsidies would contribute to economic growth. Ozorhon et al. (2018) revealed that the fiscal and taxation policies implemented by the government are critical to investment decision-making. If there are no appropriate incentives for fiscal and tax preference, renewable energy investment may decrease sharply. Johansson (2019) found that reducing financial subsidies improves investment efficiency, but increasing government subsidies will lead to excessive investment behavior. Newell et al. (2019) pointed out tax credits can encourage renewable energy enterprises to improve investment efficiency compared to onetime grants. Yang (2019) found that government subsidies have a threshold effect on renewable energy investment, and preferential tax policies can improve investment efficiency. Zhu et al. (2019) found that government subsidies can stimulate the technological innovation enthusiasm of renewable energy enterprises. Chang et al. (2020) found that government subsidies and tax rebates have a positive impact on investment efficiency of renewable energy enterprises, and the tax incentives have a greater impact. Chien et al. (2021) found that green fiscal policies, such as public supports and tax rebates, have significant role in advancing energy efficiency and reducing energy poverty.

To sum up, most research on the investment efficiency of renewable energy cooperation is from the perspective of government subsidy. A few studies focus on preferential tax policies and their impact on inefficient investment. In order to provide more precise decision-making support, it is critical to quantify various driving factors of investment efficiency. This study focuses on the impact of different green fiscal policies on the investment efficiency of renewable energy enterprises from the perspective of property heterogeneity, which makes up for the limitations of unilateral research.

Page 5/40 


\section{Hypotheses}

The Chinese government plays a vital role in the renewable energy industry through its majority ownership in SOEs and it supports both SOEs and Non-SOEs with funding and favorable policies (Zhu et al. 2019; Zhang et al. 2014; Butler et al. 2008). SOEs, as owned by the state-owned Assets Supervision and Administration Commission (SASAC), are solicited by the government to help with employment, regional development, and other social and political goals. These agenda may hinder their efficiency. Non-SOEs, most owned by individuals, receive less government intervention, and often face financial restrain, are more prudent in investment, which affect investment efficiency.

Due to asymmetric information, the renewable energy enterprises may exaggerate the losses in technical transformation and upgrading and obtain excess financial subsidies, or spend the subsidies at will (Tullock 1967). Meckling et al. (1976) pointed out that managers of renewable energy enterprises may abuse financial subsidies, which lead to over-investment. This situation is more commonly observed in SOEs, as they have a closer political connection with the government, and can obtain financial subsidies more easily. The local government's excessive pursuit of GDP assessment and integration of government administration with the enterprise has sometimes resulted in senior executives of state-owned enterprises being free to control the financial subsidies they have received without arranging detailed investment plans, which has exacerbated state-owned enterprises' excessive investment. Gu et al. (2021) pointed out that due to the unbalanced development of green finance system and information asymmetry in green finance capital input, the overall efficiency may decline. Johansson (2019) revealed that the implementation of government subsidies would lead to excessive investment behavior, and lower investment efficiency. This shows that enterprises' subsidy funds are not putting practically. Based on the preceding arguments, we come to our first hypothesis $(\mathrm{H} 1)$, which is in line with the "principal-agent" and "information asymmetry" theory (Meckling et al. 1976; Tullock 1967).

H1. Green financial subsidies will increase the over-investment of enterprises and this situation is more observable among SOEs than Non-SOEs.

Technical innovation and research and development (R\&D) activities are typical public products with positive externality and require greater capital inputs. Renewable energy companies may face higher investment risks and market failures in the R\&D process. Tax incentives provide essential compensations, and increase investment scale, and alleviate the stress of under-investment. Scholars believe that tax incentives can stimulate the initiative of renewable energy enterprises and improve their investment efficiency (Butler et al. 2008; Lokshin et al. 2011).

We also look at property rights heterogeneity and how it affects investments efficiency. When it comes to investment decisions, senior executives of SOEs are less concerned with tax advantages since they bear more social responsibility beyond profit maximization. Non-SOEs, on the contrary, are more careful in their cost-benefit analyses and are more susceptible to favorable tax policies as financial channels for Non-SOEs are relatively narrow and the capital constraints are serious. Tax incentives can reduce under-investment for the Non-SOEs. We propose our second hypothesis (H2) as follows, 
H2. Green tax preferential policies will significantly alleviate under-investment. Moreover, the green tax preferential policies will significantly alleviate the under-investment of Non-SOEs than that of SOEs.

In terms of strength, frequency, and legal considerations, green financial subsidies and tax incentives affect renewable energy firms in diverse ways. First, government subsidies provide cash flow to renewable energy businesses directly, whereas favorable tax policies have a far more indirect impact. Second, government subsidies are more frequently received, while tax incentives need to go through prolonged legislative process to get pass. However, most renewable energy companies are reticent to share specific income and expenditure information to gain economic benefits or establish a dominant position. Due to asymmetric information, they may obtain excess financial subsidies, or use the subsidies at will. Tax incentives allow smaller rent-seeking space. Furthermore, they are in legal form in terms of type and rate, allowing them to serve as normative and consistent support for renewable energy businesses.

As mentioned above, many studies believes that financial subsidies hurt investment efficiency, while tax preference positively impacts investment efficiency (Butler 2008; Lokshin 2011; Newell 2019). Financial subsidies have a more significant impact on corporate financial performance than preferential tax policies. These reasons lead us to the third hypothesis $(\mathrm{H} 3)$.

H3. Green financial subsidies and tax preference have varying effects on the investment efficiency of renewable energy companies. Green financial subsidies exacerbate the problem of over-investment and reduce the investment efficiency of renewable energy companies. Green tax incentives can help reduce insufficient investment, resulting in increased investment efficiency. Furthermore, the impact of green fiscal policies on investment efficiency will differ for businesses with different property rights.

\section{Methodology And Data}

To test our hypotheses, we introduce the Richardson model, which measures investment inefficiency. Furthermore, we introduce the fixed effect panel model, which is used to analyze the effects of green fiscal policies on renewable energy enterprises and compare the policy impacts between green financial subsidies and green tax incentives. Next, we introduce the variables and data used in the empirical analysis.

\section{Model design}

There are several quantitative analysis models available for measuring the investment efficiency of enterprises, such as the investment-cash flow sensitivity model (referred to as FHP model) (Fazzari et al. 1988), cross-product discriminant model (referred to as Vogt model) (Vogt 1994), and residual measurement model (referred to as Richardson model) (Richardson 2006). Richardson model is based on the residual of model regression to judge the level of inefficient investment. A major advantage of the Richardson model is that it can quantify the investment efficiency level of enterprises, and the inefficient investment of enterprises can be subdivided into under-investment and over-investment for comparative study. It makes up for the defects of the FHP model and Vogt model, and brings great convenience to relevant research. The quantitative analysis model is based on the residual error of the model regression. And we follow the majority of investment literature (Biddle et al. 2009; Chen et al. 2010), focusing on the new project 
investment, and test whether the Richardson model can reasonably analyze the investment efficiency of renewable energy enterprises. Specifically, we estimate the following model,

$$
\begin{aligned}
& \text { INVi,t }=\beta 0+\beta 1 \text { Growthi, } t-1+\beta 2 \text { Sizei, } t-1+\beta 3 \text { Operi, } t-1+\beta 4 \text { Agei, } t-1+\beta 5 \text { Cashi, } t-1 \\
& +\beta 6 \text { Roai, } t-1+\beta 7 \text { ADMi, } t-1+\beta 8 F C F i, t-1+\beta 9 I N V i, t-1+\sum \text { Industry }+\sum \text { Year }+\varepsilon
\end{aligned}
$$
Equation 1

where the dependent variable INV is the level of investment efficiency. It is measured as cash payments for current fixed assets, intangible assets, and other long-term assets from the cash flow statement minus cash receipts from selling these assets, scaled by beginning total assets. We introduce controls that could confound our findings. To start with, we control for a series of variables to mitigate concerns that the investment behavior we document is not merely extracting innate factors influencing both accruals quality and investment behavior. Growth represents growth opportunities, which is measured as the growth rate of primary business income. A rapid growth suggests that either the enterprise or the industry it belongs to is prosperous, and has a better chance of getting government support, which may lead to irrational investment. Size is the enterprise-scale, reflected by the natural log of total asset end-period. The bigger the size of an enterprise, the greater the advantage it has in obtaining government financial subsidies. Oper is the turnover of the total capital, which is the main business income scaled by the total asset. We expect a positive coefficient of Oper since better operating conditions and sufficient cash flow promote investment efficiency. Firm's listing age (Age) is measured by the natural logarithm of the current year minus the listing year plus 1. The longer the firm has been listed, the more experienced its executives become in investment, which improves investment efficiency. Cash is calculated by Cash and cash equivalents balance scaled by Ending cash and cash equivalents balance. Total net asset interest rate (Roa) is reflected by the ratio of net profit scaled by total assets represents the profit level of an enterprise. The strong profitability means that the enterprise can maintain ample free cash flow during operation, which affects investment efficiency directly. $A D M$ is the increasing agency costs, reflected by the management cost scaled by turnover. It makes overinvestment more serious. The higher the agency costs are, the higher the operating costs enterprises have, which will reduce investment efficiency. Due to moral hazard, when the free cash flow (FCF) is relatively abundant, executives may get more confident and tend to over-invest in pursuit of profit maximation. In addition, we introduce annual dummy variables (Year) and industry dummy variables (Indus), which were found previously to be related to capital investment.

We regress Equation 1 and extract the residual ineff, which represents the inefficient investment level of renewable energy enterprises. We set OverINV for over-investment when the residual is significantly positive and UnderINV for under-investment when the residual is significantly negative.

To test our H1, we establish Equation 2 and 3 to study the effect of green financial subsidies on the investment efficiency of renewable energy enterprises. We expect that financial subsidies can increase overinvestment, and it is more obvious in SOEs than Non-SOEs.

Ineff $_{i, t}=\alpha_{0}+\alpha_{1}$ Sub $_{i, t-1}+\alpha_{2}$ Size $_{i, t}+\alpha_{3}$ Roa $_{i, t}+\alpha_{4}$ Oper $_{i, t}$

$+\alpha_{5} A D M_{i, t}+\alpha_{6} F C F_{i, t}+\alpha_{7} A_{g e} e_{i, t}+\sum$ Industry $+\sum$ Year $+\varepsilon$ Equation 2 
OverINV $_{i, t} /$ UnderINV $_{i, t}=\alpha_{0}+\alpha_{1}$ Sub $_{i, t}-1+\alpha_{2}$ Size $_{i, t}+\alpha_{3}$ Roa $_{i, t}+\alpha_{4}$ Oper $_{i, t}$

$+\alpha_{5} A D M_{i, t}+\alpha_{6} F C F_{i, t}+\alpha_{7}$ Age $_{i, t}+\sum$ Industry $+\sum$ Year $+\varepsilon$

Equation 3

To test $\mathrm{H} 2$, we establish Equation 4 and 5, which suggest that green tax incentives can alleviate underinvestment, and it works better in SOEs than Non-SOEs. Furthermore, we compare the effects of green tax preference on over- or under-investment.

$I_{N V_{i, t}}=\beta_{0}+\beta_{1}$ tax $_{i, t-1}+\beta_{2}$ Size $_{i, t}+\beta_{3}$ Roa $_{i, t}+\beta_{4}$ Operi $_{i, t}$

$+\beta_{5} A D M_{i, t}+\beta_{6} F C F_{i, t}+\beta_{7} A g e_{i, t}+\sum$ Industry $+\sum$ Year $+\gamma$ Equation 4

$O_{\text {ver } I N V_{i, t}} /$ Under INV $_{i, t}=\beta_{0}+\beta_{1}$ taxi $_{i, t}-1+\beta_{2}$ Size $_{i, t}+\beta_{3}$ Roai $_{i, t}+\beta_{4}$ Operi $_{i, t}$

$+\beta_{5} A D M_{i, t}+\beta_{6} F_{C F} F_{i, t}+\beta_{7}$ Age $_{i, t}+\sum$ Industry $+\sum$ Year $+\gamma$

Equation 5

Based on property heterogeneity, we examine the impact of green financial subsidies and green tax incentives on the investment efficiency of renewable energy enterprises and compare their impacts. In Equation 2-5, coefficient $\alpha 1$ and $\beta 1$ are used to measure the effect of two green fiscal policies on the investment efficiency of renewable enterprises. If $\alpha 1$ is not significant, it means that government subsidies will not cause any change in the investment efficiency; if $\alpha 1$ is significantly positive, it reveals a rise in inefficient investment, suggesting that government subsidies reduce investment efficiency; if $\alpha 1$ is significantly negative, it means that government subsidies will improve investment efficiency. The analysis of the other coefficients is the same.

The explained variables in Equation 2-5 are the residuals extracted from Equation 1 after regression. The residual (ineff) is measured as the difference between actual new investment and expected investment. In addition to the control variables involved in Equation 1, we mainly examine and compare the impact of green financial subsidies and tax preference on investment efficiency. So we choose green financial subsidies (Sub) and tax preference (Tax) as explanatory variables. In addition, because we need to explore the impact of financial subsidies and tax preference on the inefficient investment of renewable energy enterprises under different property rights, it is necessary to introduce the property rights (SOE). Table 1 illustrates the variables which we are using in this study. 
Table 1

Variable description

\begin{tabular}{|c|c|c|}
\hline Variable & & Description \\
\hline \multirow[t]{3}{*}{$\begin{array}{l}\text { Explained } \\
\text { variable }\end{array}$} & Ineff & $\begin{array}{l}\text { The residual of the Richardson model regression result, the larger the } \\
\text { absolute value, the lower the investment efficiency of the enterprise. }\end{array}$ \\
\hline & OverINV & Residuals $>0$ in the Richardson model regression. \\
\hline & UnderINV & Residuals $<0$ in the Richardson regression results of model. \\
\hline \multirow{2}{*}{$\begin{array}{l}\text { Explanatory } \\
\text { variable }\end{array}$} & sub & Current green government subsidies are divided by operating income. \\
\hline & $\operatorname{tax}$ & $\begin{array}{l}\text { The tax refund received is divided by the tax refund received and the tax } \\
\text { paid. }\end{array}$ \\
\hline \multirow{11}{*}{$\begin{array}{l}\text { Control } \\
\text { variable }\end{array}$} & Growth & Primary business income growth rate. \\
\hline & Size & $\begin{array}{l}\text { This variable is measured by the Natural logarithm of total assets at the end } \\
\text { of the period. }\end{array}$ \\
\hline & Oper & Primary business income is divided by total assets. \\
\hline & Cash & $\begin{array}{l}\text { Balance of cash and cash equivalents divided by the balance of cash and } \\
\text { cash equivalents at the end of the period. }\end{array}$ \\
\hline & Age & $\begin{array}{l}\text { It is shown by the natural logarithm of the current year minus the listing year } \\
\text { plus one. }\end{array}$ \\
\hline & Roa & Net profit divided by total assets. \\
\hline & ADM & Administrative expenses are divided by operating income. \\
\hline & FCF & Free cash flow is divided by total assets at the end of the period. \\
\hline & SOE & $\begin{array}{l}\text { If it is a state-owned enterprise, } S O E=1 \text {; if it is a non-state-owned enterprise, } \\
S O E=0 \text {. }\end{array}$ \\
\hline & Year & There have eight annual dummy variables to control the annual effect. \\
\hline & Indus & There have four industry dummy variables to control industry effects. \\
\hline
\end{tabular}

\section{Sample and descriptive statistics}

Our main sample consists of 1422 firm-year observations of 228 listed renewable energy enterprises from 2010 to 2018. We eliminate ST, ST*, PT, and PT* enterprises, enterprises with major asset transactions or negative net assets value. As it is not compulsory for listed renewable energy enterprises to disclose their financial data of government subsidies and tax incentives, we exclude those enterprises with serious data missing.

Table 2 reports descriptive statistics of the explanatory variables and control variables. The mean values of government subsidies (Sub) and green tax (Tax) show that on average, renewable energy enterprises receive more government financial subsidies. However, the standard deviation of tax preference is smaller than that of government subsidies, which suggests that supports from tax incentives are more stable. Among the 
control variables, the standard deviation of enterprise Size (Size) and total asset turnover (Oper) is 1.2638 and 3.9648 respectively, indicating that the size and total asset turnover of renewable energy enterprises vary significantly. On the contrary, smaller differences are found referring to the return on total assets (Roa), agency cost $(A D M)$, free cash flow $(F C F)$.

Table 2

Descriptive statistical results of total sample explanatory variables and control variables

\begin{tabular}{|lllllll|}
\hline Variable & Sample size & Mean & Standard deviation & Minimum & Median & Maximum \\
\hline Sub & 1422 & 0.0218 & 0.0821 & 0.0000 & 0.0072 & 1.6294 \\
\hline Tax & 1422 & 0.0166 & 0.0385 & 0.0000 & 0.0056 & 0.6933 \\
\hline Size & 1422 & 22.4820 & 1.2638 & 19.0072 & 22.2890 & 26.7233 \\
\hline Roa & 1422 & 0.0320 & 0.1655 & -2.0084 & 0.0268 & 3.7057 \\
\hline Oper & 1422 & 0.8816 & 3.9648 & 0.0269 & 0.4887 & 72.4463 \\
\hline ADM & 1422 & 0.1062 & 0.2230 & 0.0035 & 0.0813 & 5.2893 \\
\hline FCF & 1422 & 0.0967 & 0.6978 & -0.3573 & 0.0369 & 14.5621 \\
\hline Age & 1422 & 2.6834 & 0.3928 & 1.7918 & 2.6391 & 3.4012 \\
\hline
\end{tabular}

We partitioned our samples based on the ownership and political connections (Table 3). SOE sample includes firms that are ultimately controlled by the governments, including the central government and local governments at the provincial, municipal, and county level, or other governmental institutions. The Non-SOE sample includes firms whose ultimate controlling shareholders are individuals or non-state entities, including town-village enterprises, foreign enterprises, or other non-state-controlled enterprises. A firm is defined as a connected one if its chairman or CEO is a current or previous government official. Compared with Non-SOEs, SOEs are generally on a bigger scale and longer listing time. However, the average level of Non-SOEs in terms of over- or under-investment level, cash holding, return on assets, total asset turnover rate, agency cost, and free cash flow are higher than that of SOEs. A likely explanation is that these Non-SOEs are less reliable to the government and have to efficiently support themselves. 
Table 3

Descriptive statistical results of explanatory variables and control variables of SOEs and Non-SOEs

\begin{tabular}{|lllllllll|}
\hline Variable & SOEs & \multicolumn{7}{c|}{ Non-SOEs } \\
\cline { 2 - 7 } & $\begin{array}{l}\text { Sample } \\
\text { size }\end{array}$ & Mean & $\begin{array}{l}\text { Standard } \\
\text { deviation }\end{array}$ & Median & $\begin{array}{l}\text { Sample } \\
\text { size }\end{array}$ & Mean & $\begin{array}{l}\text { Standard } \\
\text { deviation }\end{array}$ & Median \\
\hline sub & 531 & 0.0178 & 0.0390 & 0.0058 & 891 & 0.0241 & 0.0992 & 0.0078 \\
\hline tax & 531 & 0.0098 & 0.0142 & 0.0044 & 891 & 0.0206 & 0.0469 & 0.0076 \\
\hline Size & 531 & 22.9253 & 1.2734 & 22.7100 & 891 & 22.2178 & 1.1822 & 22.0404 \\
\hline Cash & 531 & 0.7431 & 1.3627 & 0.4023 & 891 & 0.9696 & 7.5664 & 0.2361 \\
\hline Roa & 531 & 0.0195 & 0.0542 & 0.0215 & 891 & 0.0395 & 0.2045 & 0.0316 \\
\hline Oper & 531 & 0.5527 & 0.3340 & 0.4781 & 891 & 1.0776 & 4.9929 & 0.4970 \\
\hline ADM & 531 & 0.0884 & 0.1261 & 0.0701 & 891 & 0.1168 & 0.2639 & 0.0858 \\
\hline FCF & 531 & 0.0497 & 0.0852 & 0.0457 & 891 & 0.1247 & 0.8780 & 0.0327 \\
\hline Age & 531 & 2.9680 & 0.3075 & 3.0445 & 891 & 2.5137 & 0.3360 & 2.4849 \\
\hline
\end{tabular}

The standard deviation of government subsidies for SOEs is 0.0390 , which is bigger than that of the tax preference, suggesting that SOEs vary more in government subsidies receival. A similar pattern is found among Non-SOEs. Among the control variables, the standard deviation of enterprise size and cash holding rate is large, indicating that there are significant differences among these variables. On the contrary, the standard deviations of return on total assets (Roa), agency cost $(A D M)$, free cash flow $(F C F)$, and listing Age (Age) are small, indicating that the difference is small for both state-owned and non-state-owned renewable energy enterprises.

\section{Empirical Results And Discussions}

\section{Analysis of investment efficiency of renewable energy enterprises}

First, the unit root test (LLC test and Fisher-ADF test) was used to test the stationarity of related sequences. All sequences were stationary (Table 4). Then we applied the co-integration test (Table 5) to check the longterm equilibrium relationship. Next, we select the appropriate panel data model among fixed effects model (FE), random effects model (RE), and mixed regression model (OLS) using F test, LM test, and Hausman test. Based on results from Table 6, 7, and 8, The Richardson model (Equation 1) should be used to measure the efficiency of business investment using the fixed effects model for regression. 
Table 4

Unit root test results. The results show that all the series are stationary and have passed the $1 \%$ significance level. $* * *, * *$ * indicate significance at $1 \%, 5 \%$, and $10 \%$ respectively.

\begin{tabular}{|c|c|c|c|c|c|}
\hline Variable & LLC & P-value & Fisher-ADF & P-value & Conclusion \\
\hline INV & -37.4671 & $0.0000 * \star *$ & 1106.0778 & 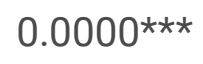 & stationary \\
\hline Growth & -11.4559 & $0.0000 * \star *$ & 583.8697 & $0.0000 * \star \star$ & stationary \\
\hline Size & -30.4746 & $0.0000 * \star *$ & 528.1121 & $0.0000 * \star *$ & stationary \\
\hline Cash & -25.5279 & $0.0000 * * *$ & 1075.7322 & $0.0000 * \star \star$ & stationary \\
\hline Age & -31.9602 & $0.0000 * * *$ & 962.8135 & $0.0000 * \star \star$ & stationary \\
\hline Roa & -32.2905 & $0.0000 * \star \star *$ & 1110.8877 & $0.0000 * \star \star *$ & stationary \\
\hline ADM & -49.2948 & $0.0000 * * *$ & 765.1309 & $0.0000 * \star *$ & stationary \\
\hline FCF & $-1.7 e+02$ & $0.0000 * \star \star *$ & 1582.2834 & $0.0000 * \star \star *$ & stationary \\
\hline Oper & $-1.4 e+03$ & $0.0000 * * *$ & 3933.4635 & $0.0000 * \star \star$ & stationary \\
\hline
\end{tabular}


Table 5

Panel Co-integration Test Results. The detailed results of a within-group, between-group, and unit root test are shown in Table 5, which test result verifies the Richardson model's rationality. The $P$-value corresponding to each statistic is in the brackets. $\star \star \star, ~ * \star, ~ *$ indicate significance at $1 \%, 5 \%$, and $10 \%$ respectively.

\begin{tabular}{|c|c|c|c|c|}
\hline Variable & Within-group statistics & P-value & Between-group statistics & P-value \\
\hline \multirow[t]{4}{*}{ INV and Growth } & Pand PP & -18.2806 & Group PP & -17.2806 \\
\hline & & $(0.0000 * \star \star)$ & & $(0.0000 * \star \star)$ \\
\hline & Panel ADF & -18.2808 & Group ADF & -18.7389 \\
\hline & & $(0.0000 * \star \star)$ & & $\left(0.0000^{\star \star \star}\right)$ \\
\hline \multirow[t]{4}{*}{ INV and Cash } & Pand PP & -18.6846 & Group PP & -16.5491 \\
\hline & & $(0.0000 * \star \star)$ & & $(0.0000 * \star *)$ \\
\hline & Panel ADF & -18.0018 & Group ADF & -17.6434 \\
\hline & & $(0.0000 * \star \star)$ & & $(0.0000 * \star \star)$ \\
\hline \multirow[t]{4}{*}{ INV and Oper } & Pand PP & -18.5216 & Group PP & -16.4806 \\
\hline & & $(0.0000 * \star \star)$ & & $(0.0000 * * *)$ \\
\hline & Panel ADF & -17.9736 & Group ADF & -18.0842 \\
\hline & & $(0.0000 * * \star)$ & & $(0.0000 * \star \star)$ \\
\hline \multirow[t]{4}{*}{ INV and Age } & Pand PP & -18.1806 & Group PP & -16.0918 \\
\hline & & $(0.0000 * * \star)$ & & $(0.0000 * \star \star)$ \\
\hline & Panel ADF & -20.1854 & Group ADF & -19.7908 \\
\hline & & $(0.0000 * \star \star)$ & & $(0.0000 * \star \star)$ \\
\hline \multirow[t]{4}{*}{ INV and Size } & Pand PP & -18.3806 & Group PP & -16.5846 \\
\hline & & $(0.0000 * \star \star)$ & & $(0.0000 * \star *)$ \\
\hline & Panel ADF & -19.3548 & Group ADF & -20.0867 \\
\hline & & $(0.0000 * \star \star)$ & & $(0.0000 * \star \star)$ \\
\hline \multirow[t]{4}{*}{ INV and Roa } & Pand PP & -19.0806 & Group PP & -16.6578 \\
\hline & & $(0.0000 * \star \star)$ & & $(0.0000 * \star \star)$ \\
\hline & Panel ADF & -18.6808 & Group ADF & -17.3468 \\
\hline & & $(0.0000 * * \star)$ & & $(0.0000 * \star \star)$ \\
\hline \multirow[t]{2}{*}{ INV and ADM } & Pand PP & -19.5416 & Group PP & -16.2713 \\
\hline & & $(0.0000 * \star \star)$ & & $(0.0000 \star \star \star)$ \\
\hline
\end{tabular}




\begin{tabular}{|c|c|c|c|c|}
\hline Variable & Within-group statistics & P-value & Between-group statistics & P-value \\
\hline & \multirow[t]{2}{*}{ Panel ADF } & -18.0446 & \multirow[t]{2}{*}{ Group ADF } & -17.1935 \\
\hline & & $(0.0000 * \star \star)$ & & $(0.0000 * * *)$ \\
\hline \multirow[t]{4}{*}{ INV and FCF } & \multirow[t]{2}{*}{ Pand PP } & -19.0392 & \multirow[t]{2}{*}{ Group PP } & -16.1450 \\
\hline & & $(0.0000 * * \star)$ & & $(0.0000 * * *)$ \\
\hline & \multirow[t]{2}{*}{ Panel ADF } & -18.2933 & \multirow[t]{2}{*}{ Group ADF } & -17.3386 \\
\hline & & $(0.0000 * \star \star)$ & & $(0.0000 * * *)$ \\
\hline
\end{tabular}

Table 6

LM test results. LM test selects between random effects model and mixed regression model. $P$-value is zero, the random effects model should be selected.

\begin{tabular}{|lll|}
\hline Variable & Var & Sd=sqrt(Var) \\
\hline INV & 0.0027 & 0.0519 \\
\hline e & 0.0019 & 0.0435 \\
\hline u & 0.0006 & 0.0253 \\
\hline Test:Var(u) $=0$ & \\
\hline Chibar2(01) $=293.48$ & \\
\hline
\end{tabular}


Table 7

Hausma test result. Hausman test selects between random effect model and fixed effect model. The $P$-value is zero, the fixed effect model is more suitable for the regression study in this paper.

\begin{tabular}{|lllll|}
\hline Variable & $\mathbf{( b )}$ & $\mathbf{( B )}$ & $\mathbf{( b - B )}$ & sqrt(diag(V_b-V_B)) \\
\hline Growth & 0.0006 & 0.0015 & -0.0008 & 0.0004 \\
\hline Size & -0.0001 & 0.0006 & -0.0008 & 0.0032 \\
\hline Cash & -0.0007 & -0.0009 & 0.0002 & 0.0001 \\
\hline Age & -0.0601 & -0.0154 & -0.0448 & 0.0294 \\
\hline Roa & 0.0135 & 0.0192 & -0.0057 & 0.0053 \\
\hline ADM & -0.0132 & -0.0157 & 0.0025 & 0.0055 \\
\hline FCF & 0.0235 & 0.0297 & -0.0062 & 0.0081 \\
\hline Oper & -0.0046 & -0.0055 & 0.0010 & 0.0014 \\
\hline INV & 0.2663 & 0.4758 & -0.2094 & 0.0166 \\
\hline Chi2(9)=11.08 & & & \\
\hline Prob>chi2=0.0000 & & & \\
\hline
\end{tabular}

The regression result of the Richardson model (Table 8 ) shows that R-square is 0.5929 , indicating that the model can jointly explain $59.29 \%$, and it also reflects that the Equation 1 fits well. After regression, residual is extracted (Ineff), which represents the deviation of investment efficiency from optimal investment is investigated. The positive residual value (OverINV), representing over-investment; while UnderINVhas a negative value, representing under-investment. 
Table 8

Richardson model regression results

\begin{tabular}{|lllll|}
\hline INV & Coefficient & Standard deviation & T-statistic & P-value \\
\hline Growth & -0.0027 & 0.0003 & -1.02 & 0.0080 \\
Cash & 0.0073 & 0.0541 & 1.34 & 0.0018 \\
\hline Size & -0.0016 & 0.0014 & -1.20 & 0.0023 \\
\hline Roa & 0.0215 & 0.0139 & 1.55 & 0.0012 \\
\hline Oper & -0.0070 & 0.0023 & -3.05 & 0.0002 \\
\hline ADM & -0.0214 & 0.0079 & -2.72 & 0.0007 \\
\hline FCF & 0.0362 & 0.0141 & 2.57 & 0.0010 \\
\hline Age & -0.0225 & 0.0038 & -5.85 & 0.0000 \\
\hline INV & 0.3254 & 0.0254 & 12.78 & 0.0000 \\
\hline -cons & 0.1604 & 0.0301 & -5.32 & 0.0000 \\
\hline R-square=0.5929 & & F statistic=12.20 & & \\
\hline Adjusted R-square=0.5839 & Mean of dependent variable=0.0598 \\
\hline Regression standard deviation=0.0553 & Dependent variable variance=0.1225 \\
\hline
\end{tabular}

We use an aggregated measure of residual to classify firms by the likelihood that they will over- or underinvest. Table 9 provides the summary statistics for the inefficiency of renewable energy enterprises. We can see that 834 out of 1422 observations are under-invested, accounting for $58.65 \%$ of the sample, while 588 over-investment, accounting for $41.35 \%$ of the sample. A higher tendency of under-investment indicates that renewable enterprises are more likely to give up profitable investment projects when they face financing constraints. Government subsidies and tax preference can alleviate financial difficulties, but it may also bring overconfidence to executives which lead to irrational investment decision.

Table 9

Descriptive statistical results of inefficient investment of renewable energy enterprises

\begin{tabular}{|lllllll|}
\hline Variable & Sample size & Mean & Standard deviation & Minimum & Median & Maximum \\
\hline OverINV & 588 & 0.0479 & 0.0474 & 0.0000 & 0.0336 & 0.3591 \\
UnderINV & 834 & -0.0337 & 0.0239 & -0.3280 & -0.0322 & -0.0000 \\
\hline Ineff & 1422 & 0.0000 & 0.0536 & -0.3280 & -0.0105 & 0.3591 \\
\hline
\end{tabular}

Next, we focus on the perspective of property heterogeneity and see if renewable enterprises would behave differently on investment efficiency. Table 10 reports descriptive statistics on Ineff of renewable energy enterprises. Among SOEs, the number of under-invested enterprises (288) is more than the number of overinvested enterprises (243). Among Non-SOEs, the number of under-invested enterprises (546) is also more than the number of over-invested enterprises (345). Therefore, in renewable energy enterprises, under-invest 
problem is more observable among Non-SOEs. However, for both SOEs and Non-SOEs, the degree of overinvestment is more serious than under-investment in renewable energy enterprises.

Table 10

Descriptive statistical results of inefficient investment of SOEs and Non-SOEs

\begin{tabular}{|llllllll|}
\hline & Variable & $\begin{array}{l}\text { Sample } \\
\text { size }\end{array}$ & Mean & $\begin{array}{l}\text { Standard } \\
\text { deviation }\end{array}$ & Minimum & Median & Maximum \\
\hline SOEs & Ineff & 531 & 0.0041 & 0.0501 & -0.1077 & -0.0058 & 0.3591 \\
\cline { 2 - 8 } & OverINV & 243 & 0.0433 & 0.0479 & 0.0002 & 0.0297 & 0.3591 \\
\cline { 2 - 8 } & UnderINV & 288 & -0.0289 & 0.0174 & -0.1077 & -0.0284 & -0.0009 \\
\hline $\begin{array}{l}\text { Non- } \\
\text { SOEs }\end{array}$ & Ineff & 891 & -0.0025 & 0.0555 & -0.3280 & -0.0141 & 0.2320 \\
& OverINV & 345 & 0.0510 & 0.0468 & 0.0000 & 0.0364 & 0.2320 \\
& UnderINV & 546 & -0.0363 & 0.0263 & -0.3280 & -0.0357 & -0.0000 \\
\hline
\end{tabular}

\section{Impact of government subsidies on investment efficiency of renewable energy enterprises}

The Pearson correlation analysis of all variables is carried out to prevent the multicollinearity of model design variables and ensure the validity of parameters (Table 11). Variance inflation factor test is applied with over-and under-investment as explanatory variables (Table 12). Results suggest that the variables pass the multicollinearity test and can be carried on to the next step of research. There are some interesting findings referring to the control variables in the Pearson test. The significant negative coefficients on Age and Oper imply that the higher total asset turnover and the longer listing Age lead to higher investment efficiency. Investment efficiency is positively related to agency cost $(A D M)$, suggesting that agency cost will aggravate the inefficient investment of renewable energy enterprises. The larger the company (Size), the more severe the over-investment, while the under-investment can be mitigated. Abundant free cash flow $(F C F)$ is positively correlated with over-investment. A higher return on assets (Roa) is negatively correlated with over-investment. But we find no significant influence of FCF and Roa on under-investment. 
Table 11

Pearson Correlation for these variables. * denote significance at the $5 \%$ level.

\begin{tabular}{|c|c|c|c|c|c|c|}
\hline & OverINV & UnderINV & Sub & Tax & Size & Roa \\
\hline OverINV & 1 & & & & & \\
\hline UnderINV & - & 1 & & & & \\
\hline Sub & $0.1095^{\star}$ & $-0.1198 *$ & 1 & & & \\
\hline Tax & 0.0498 & $-0.0779 *$ & -0.0893 & 1 & & \\
\hline Size & $0.0783^{*}$ & $-0.0319 *$ & $0.1359 *$ & $-0.1382^{*}$ & 1 & \\
\hline Roa & $-0.1162^{\star}$ & -0.0171 & -0.0455 & $-0.0839 *$ & -0.0009 & 1 \\
\hline Oper & $-0.1300 *$ & $-0.1161^{\star}$ & -0.0310 & -0.0370 & -0.0674 & $0.5759 *$ \\
\hline ADM & $0.0428^{*}$ & $0.0037 *$ & $0.0994^{*}$ & $0.0832^{\star}$ & $-0.1534^{\star}$ & -0.1700 * \\
\hline FCF & $0.1420 *$ & -0.0122 & 0.0169 & -0.0413 & -0.0502 & $0.5157 *$ \\
\hline \multirow[t]{2}{*}{ Age } & $-0.5717^{\star}$ & $-0.7741^{*}$ & 0.0495 & $-0.1605^{\star}$ & $0.2705^{\star}$ & $-0.1133^{\star}$ \\
\hline & Oper & ADM & FCF & Age & & \\
\hline Oper & 1 & & & & & \\
\hline ADM & -0.0412 & 1 & & & & \\
\hline FCF & $0.5824^{\star}$ & 0.0306 & 1 & & & \\
\hline Age & $-0.1279 *$ & $-0.1135^{\star}$ & $-0.1310 *$ & 1 & & \\
\hline
\end{tabular}


Table 12

Multicollinearity test results. Through testing, we find that the maximum value of VIF is $2.45<10$, and the mean of VIF tested with over-investment and under-investment as explained variables are more significant than 1 . This result shows no multicollinearity between the variables in the regression model selected in this paper.

\begin{tabular}{|lll|}
\hline Variable & Explained variable (over-investment) & Explained variable (under-investment) \\
\cline { 2 - 3 } & VIF & VIF \\
\hline Roa & 2.45 & 1.31 \\
\hline FCF & 2.39 & 1.07 \\
\hline ADM & 1.15 & 1.66 \\
\hline Age & 1.09 & 1.12 \\
\hline sub & 1.06 & 1.15 \\
\hline Oper & 1.04 & 1.03 \\
\hline Size & 1.04 & 1.22 \\
\hline tax & 1.03 & 1.30 \\
\hline MeanVIF & 1.41 & 1.23 \\
\hline
\end{tabular}

Furthermore, the regression analysis of the total sample (Ineff), over-investment (overINV), and underinvestment (UnderINV) data according to Equation (2) and Equation (3) is as follows (Table 13). 
Table 13

Regression results of subsidy policy on investment efficiency of renewable energy enterprises

\begin{tabular}{|c|c|c|c|}
\hline Variable & Ineff & overINV & UnderINV \\
\hline \multirow[t]{2}{*}{ sub } & $0.0405^{* *}$ & 0.1236 ** & $-0.0307 *$ \\
\hline & [2.3949] & [2.8521] & {$[-1.3690]$} \\
\hline \multirow[t]{2}{*}{ Size } & $0.0099 * \star *$ & $0.0126^{\star \star *}$ & $-0.0036^{\star}$ \\
\hline & [8.0925] & [9.8986] & {$[-1.8282]$} \\
\hline \multirow[t]{2}{*}{ Roa } & $-0.0340 * \star$ & $-0.0324^{\star \star}$ & -0.0298 \\
\hline & {$[-2.5607]$} & {$[-2.0007]$} & [-1.3329] \\
\hline \multirow[t]{2}{*}{ Oper } & $-0.0095^{\star \star \star}$ & $-0.0083 * * *$ & $-0.0107 * \star \star *$ \\
\hline & [-4.3273] & [-2.9323] & {$[-2.8061]$} \\
\hline \multirow[t]{2}{*}{ ADM } & $0.0202^{\star \star \star}$ & $0.0200 * *$ & $0.0418^{* *}$ \\
\hline & [2.7349] & [2.3124] & [2.0818] \\
\hline \multirow[t]{2}{*}{ FCF } & $0.0559 * \star \star$ & $0.0507 * \star \star *$ & $-0.0779 * \star *$ \\
\hline & [4.1629] & [2.9377] & [-3.2096] \\
\hline \multirow[t]{2}{*}{ Age } & $-0.3039 * * *$ & $-0.2127 * \star \star$ & $-0.2559 * \star \star *$ \\
\hline & [-70.8989] & {$[-19.9511]$} & {$[-36.5666]$} \\
\hline Indus & Controlled & Controlled & Controlled \\
\hline Year & Controlled & Controlled & Controlled \\
\hline \multirow[t]{2}{*}{ _cons } & -0.0032 & $0.1534^{\star \star \star}$ & 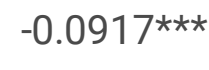 \\
\hline & {$[-0.1152]$} & [3.7020] & [-5.5962] \\
\hline$N$ & 1422 & 588 & 834 \\
\hline adj.R-sq & 0.0933 & 0.0713 & 0.0742 \\
\hline
\end{tabular}

In the case of the total sample, after controlling Size, Oper, Roa, ADM, FCF, and Age, green government subsidies and inefficient investment are positively and significantly related (correlation of 0.0405 ). The more green government subsidies been received, the severe the investment inefficiency. Secondly, in sub-samples, green financial subsidies and over- and under-investment are positively and significantly related (correlation of 0.1236), while green financial subsidies and under-investment are negatively and significantly related (correlation of -0.0307). On the one hand, renewable energy enterprises are highly dependent on policies. With the issuance of financial subsidies, managers are most likely to use subsidies to make blindly optimistic investments. On the other hand, green financial subsidies are pure cash flow that is directly 
obtained from the government free of charge. These money assets help alleviate financing constraints of the renewable energy enterprises and improve the under-investment. In summary, for renewable energy enterprises, this shows that the increase in government subsidies leads to over-investment, which verifies $\mathrm{H} 1$. However, for the enterprise with financing constraints, the increase in government subsidies can alleviate financial problems and improve investment efficiency.

Among the control variables, the regression coefficients of enterprise Size and inefficient investment, overinvestment, and under-investment of renewable energy enterprises were $0.0099,0.0126$, and -0.0036 respectively. This indicates that with business expansion, enterprises may reach scale economy and have better chance receiving government subsidies, which will alleviate under-investment problem. But money abundancy may also cause overconfidence and blind investment which leads to excessive investment and low investment efficiency of renewable energy enterprises.

In terms of the interaction between return on total assets (Roa) and investment inefficiency, we find that the estimated coefficient is negative and significant (correlation is -0.0340), and that of excessive investment is -0.0324. It indicates that the higher the return on assets of the enterprise, the higher the utilization efficiency of the capital invested by shareholders, that is, the better the profitability of the enterprise, which can inject a large amount of funds into the R\&D innovation of the enterprise, to effectively alleviate the phenomenon of excessive investment of renewable energy enterprises. The higher the rate of return on assets, the better enterprises can make use of sufficient profit funds for investment activities, seize good investment projects, and make wiser investment decisions, to improve the investment efficiency of renewable energy enterprises more effectively.

When we turn our attention to the corporate governance variables, we find that the estimated coefficients of total asset turnover (Oper) and listing Age (Age) are both negative (correlations are -0.0095 and -0.3039 respectively). This indicates that the longer the listing time and the higher the total asset turnover of renewable energy enterprises, the higher the investment efficiency of enterprises. Because valuable experiences can be accumulated through continuous corporate operating, which can promote the efficiency of investment projects. Moreover, the funds of renewable energy enterprises can be rationally allocated to investment projects, which significantly improves the investment efficiency of renewable energy enterprises.

In terms of the regression coefficients of agency costs $(A D M)$ and inefficient investment, over-investment and under-investment of renewable energy enterprises were $0.0202,0.0200$, and 0.0418 respectively. We find that the estimated coefficients of agency costs are all positive and significant. On the one hand, it shows that with the increase of renewable energy enterprise agency cost, the operating cost increases gradually, which will greatly cut into the funds invested in profitable projects, leading to inadequate investment. On the other hand, it shows that agency costs increase will exacerbate the interest conflicts between executives and shareholders, making the firm is more likely to over-invest. The regression coefficients of free cash flow (FCF) and inefficient investment and over-investment of renewable energy enterprises were 0.0559 and 0.0507 respectively. The interaction between free cash flow and under-investment, we find that the estimated coefficient is negative and significant (correlation is -0.0779). These indicate that when the free cash flow is more abundant, enterprises will use spare money to invest. Due to the existence of moral hazard, executives

Page 22/40 
seeking to maximize their interests through blind investment will aggravate the excessive investment of the enterprise, thus reducing the corporate investment efficiency. However, lots of free cash flow can alleviate the under-investment of enterprises to a certain extent.

\section{Impact of tax preference on investment efficiency of renewable energy enterprises}

The regression analysis of the total sample (Ineff), over-investment (overINV), and under-investment (UnderINV) according to Equation (4) and Equation (5) is shown in Table 14. The regression coefficient of Tax in the total sample is significantly negative, indicating a negative relation between green tax preference and inefficient investment of renewable energy enterprises (-0.0096). In the case of sub-samples, the result indicates that the coefficient associated with over- and under-investment are also negative in both cases but only significant for the under-investment (with t-value of 2.7532). As the government implements more green tax preferential policies, financial restrain will be alleviated for the renewable energy enterprises. The result from Table 14 supports $\mathrm{H} 2$ that green tax preferences will relieve under-investment and improve the investment efficiency of renewable energy enterprises. This finding is similar to the research conclusions of Butler et al. (2008), Lokshin et al. (2011), and Newell (2019). 
Table 14

Regression results of tax preference on investment efficiency of renewable energy enterprises

\begin{tabular}{|c|c|c|c|}
\hline Variable & Ineff & OverINV & UnderINV \\
\hline \multirow[t]{2}{*}{$\operatorname{tax}$} & $-0.0096 * *$ & -0.0658 & $-0.0071 * *$ \\
\hline & [2.7426] & [1.4532] & [2.7532] \\
\hline \multirow[t]{2}{*}{ Size } & $0.0103^{\star \star \star}$ & $0.0132^{\star \star \star}$ & $-0.0034^{\star}$ \\
\hline & [8.5421] & [10.5348] & {$[-1.7654]$} \\
\hline \multirow[t]{2}{*}{ Roa } & $-0.0329 \star \star$ & $-0.0335^{\star \star}$ & -0.0299 \\
\hline & [-2.4666] & {$[-2.0566]$} & [-1.3216] \\
\hline \multirow[t]{2}{*}{ Oper } & $-0.0092^{\star \star \star}$ & $-0.0081^{\star * *}$ & $-0.0094^{\star \star}$ \\
\hline & [-4.1557] & [-2.8776] & [-2.4679] \\
\hline \multirow[t]{2}{*}{ ADM } & $0.0209 \star \star \star *$ & $0.0179 * \star$ & $0.0456 * *$ \\
\hline & [2.8196] & [2.0806] & [2.0983] \\
\hline \multirow[t]{2}{*}{ FCF } & $0.0536 * \star \star$ & $0.0498 * \star \star$ & $-0.0712^{\star \star \star}$ \\
\hline & [3.9933] & [2.8782] & {$[-2.9401]$} \\
\hline \multirow[t]{2}{*}{ Age } & $-0.3050 * \star *$ & $-0.2154^{\star \star \star}$ & $-0.2583^{\star \star \star}$ \\
\hline & {$[-71.1689]$} & {$[-20.3447]$} & {$[-36.7556]$} \\
\hline Indus & Controlled & Controlled & Controlled \\
\hline Year & Controlled & Controlled & Controlled \\
\hline \multirow[t]{2}{*}{ _cons } & -0.011 & $0.1524^{\star \star \star}$ & 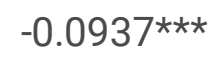 \\
\hline & {$[-0.3914]$} & [3.6971] & {$[-5.6803]$} \\
\hline$N$ & 1422 & 588 & 834 \\
\hline $\operatorname{adj} . R-s q$ & 0.0896 & 0.0732 & 0.0662 \\
\hline
\end{tabular}

Our analysis so far has demonstrated that the green preferential tax policies alleviate the under-investment and improve the investment efficiency of enterprises. On the one hand, tax preference can help reduce the tax burden of renewable energy enterprises and provide a strong guarantee for corporate R\&D and innovation. It also alleviates under-investment due to a shortage of funds. On the other hand, preferential tax policies can provide great incentives for renewable energy enterprises to apply state-to-art technology, which leads to higher production efficiency and more corporate earnings. Enterprises will have more funds to invest in other profitable projects and a virtuous circle is created. 
In summary, according to the regression results of Table 13 and 14, the effect of green tax preference on the investment efficiency of renewable energy enterprises is less than that of green financial subsidies. The reason is that green financial subsidies are the most direct means of green fiscal policy. This green fiscal policy can inject large amounts of cash flow into renewable energy enterprises facing financing constraints and impact investment efficiency directly. On the contrary, the impact of green tax preferential policies is limited because the preferential tax policies cannot bring cash to renewable energy enterprises directly. For renewable energy enterprises that need many funds for development and promotion, preferential tax policies do not impact investment efficiency immediately. This result verifies our hypothesis that the effects of green financial subsidies and tax incentives on the investment efficiency of renewable energy enterprises are different. Among them, government subsidies have a more significant impact on the investment efficiency of enterprises than preferential tax policies.

\section{Impact of government subsidies on investment efficiency in SOEs versus Non-SOEs}

Next, we examine how government subsidies impact investment efficiency according to the ownership and political connections for SOEs versus Non-SOEs. The regression uses over-investment (OverINV) and underinvestment (UnderINV) as the explained variables, and green financial subsidies (sub) as the explanatory variable, the comparable findings are shown in Table 15. 
Table 15

Regression results of government subsidies on investment efficiency of renewable energy enterprises, SOEs versus Non-SOEs

\begin{tabular}{|c|c|c|c|c|}
\hline \multirow[t]{2}{*}{ Variable } & \multicolumn{2}{|l|}{ SOEs } & \multicolumn{2}{|l|}{ Non-SOEs } \\
\hline & OverINV & UnderINV & OverINV & UnderINV \\
\hline \multirow[t]{2}{*}{ sub } & $0.2588 * \star$ & -0.0788 & $0.1442 *$ & -0.0135 \\
\hline & [1.5588] & {$[-1.0808]$} & [1.4117] & [-0.9034] \\
\hline \multirow[t]{2}{*}{ Size } & $0.0127^{\star \star}$ & 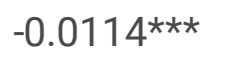 & $0.0062^{\star \star \star}$ & $-0.0139 * \star *$ \\
\hline & [2.3929] & [-6.9424] & [2.9775] & [-5.9994] \\
\hline \multirow[t]{2}{*}{ Roa } & -0.2965 & $-0.0607 * \star$ & -0.0256 & $-0.1083^{* * *}$ \\
\hline & [1.1225] & [2.0557] & [-1.5991] & [-2.8583] \\
\hline \multirow[t]{2}{*}{ Oper } & $-0.0822^{\star \star \star}$ & $-0.0340 * \star \star$ & $-0.0058^{\star *}$ & 0.0024 \\
\hline & [-3.5259] & [-6.2673] & [-1.9964] & [0.4186] \\
\hline \multirow[t]{2}{*}{ ADM } & $0.2331^{\star * \star}$ & 0.0485 & 0.0122 & $0.0864^{\star \star \star}$ \\
\hline & [4.1749] & [1.5573] & [1.4236] & [2.7778] \\
\hline \multirow[t]{2}{*}{ FCF } & $0.3748 * \star \star$ & $-0.0973^{\star \star \star \star}$ & $0.0355^{\star \star}$ & -0.0466 \\
\hline & [4.2091] & [-3.1907] & [1.9947] & [-1.1514] \\
\hline \multirow[t]{2}{*}{ Age } & $-0.2100^{\star \star \star}$ & $-0.2444^{\star \star \star}$ & $-0.2203^{\star \star \star}$ & $-0.2775^{\star \star \star}$ \\
\hline & [-7.5233] & [-26.0392] & {$[-18.4290]$} & [-23.8145] \\
\hline \multirow[t]{2}{*}{ _cons } & $0.3282^{\star * \star}$ & $-0.1625^{\star \star \star}$ & $0.1514^{\star \star \star}$ & $-0.0664 * * *$ \\
\hline & [4.5107] & [-6.7582] & [2.6389] & [-3.0289] \\
\hline $\mathrm{N}$ & 243 & 288 & 345 & 546 \\
\hline adj.R-sq & 0.1558 & 0.1502 & 0.0517 & 0.0701 \\
\hline
\end{tabular}

Column (2) and (3) of Table 15 examine the over- or under-investment impact that green government subsidies have on SOEs. There is a significant positive association between green subsidies and overinvestment (0.2588). The relationship between green subsidies and under-investment is negative, but not statistically significant, which suggests that green government subsidies tend to aggravate over-invest for SOEs. However, the effect of government subsidies on under-investment is not significant.

Columns (4) and (5) of Table 15 examine over- or under-investment impact that green government subsidies have on the Non-SOEs. Similarly, there is a significant positive association between green subsidies and over-investment (0.1442), while the relationship between green subsidies and under-investment is negative, it's not statistically significant (with t-statistics ranging from 1.4117 to -0.9034 ). 
In general, as subsidies increase, it aggravates over-investment for both SOEs and Non-SOEs. However, it is worth noticing that the over-investment impact that green subsidies have on the SOEs is higher than that of the Non-SOEs. These results confirm $\mathrm{H} 1$ and $\mathrm{H} 3$ that green financial subsidies significantly increase the overinvestment of SOEs than that of Non-SOEs. State -owned renewable energy enterprises have a comparative advantage in getting financial subsidies and become cash-rich, but the executives may drive SOEs into less optimal investment decisions. They may need to put social responsibility prior to profit maximation, or they are lack of investment experience or purely over-optimistic, as they believe the risks will be bailed out and losses would be covered by the government subsidies. Therefore, government subsidies hurt the investment efficiency of SOEs in some ways. Next, we further explore whether the impact of green tax incentives on enterprise investment efficiency varies for enterprises with different ownerships.

\section{Impact of tax preference on investment efficiency in SOEs versus Non-SOEs}

The section below describes how tax preference impacts investment efficiency according to the ownership and political connections for SOEs versus Non-SOEs. The regression using over-investment (OverINV) and under-investment (UnderINV) as the explained variables, and tax preference (tax) as the explanatory variable, the comparable findings are shown in Table 16. 
Table 16

Regression results of tax preference on investment efficiency of renewable energy enterprises, SOEs versus Non-SOEs

\begin{tabular}{|c|c|c|c|c|}
\hline \multirow[t]{2}{*}{ Variable } & \multicolumn{2}{|l|}{ SOEs } & \multicolumn{2}{|l|}{ Non-SOEs } \\
\hline & OverINV & UnderINV & OverINV & UnderINV \\
\hline \multirow[t]{2}{*}{$\operatorname{tax}$} & -0.5203 & -0.2555 & -0.0072 & $-0.0978 * *$ \\
\hline & [-1.1122] & {$[-1.1058]$} & {$[-0.1668]$} & {$[-2.1941]$} \\
\hline \multirow[t]{2}{*}{ Size } & $-0.0143^{\star \star \star}$ & $0.0124^{\star \star \star}$ & $0.0062^{\star \star \star}$ & $0.0147^{\star \star \star \star}$ \\
\hline & [-2.7287] & [7.8240] & [2.9450] & [6.6814] \\
\hline \multirow[t]{2}{*}{ Roa } & 0.2916 & $0.0536^{*}$ & $-0.0272^{\star}$ & $-0.1061^{\star \star \star \star}$ \\
\hline & [1.0905] & [1.7950] & [-1.6907] & [-2.7956] \\
\hline \multirow[t]{2}{*}{ Oper } & $-0.0851^{\star \star \star}$ & $-0.0332^{\star \star \star}$ & $-0.0058 * \star$ & 0.0037 \\
\hline & {$[-3.6508]$} & [-6.1964] & [-1.9956] & [0.6521] \\
\hline \multirow[t]{2}{*}{ ADM } & $0.1902^{\star * *}$ & $0.0679 * \star$ & 0.0103 & $0.0764 * \star$ \\
\hline & [3.7906] & [2.1077] & [1.1986] & [2.3036] \\
\hline \multirow[t]{2}{*}{ FCF } & $0.3056^{\star \star \star}$ & $-0.0825^{\star \star \star}$ & $0.0355^{\star \star}$ & -0.0434 \\
\hline & [3.7901] & [-2.7889] & [1.9906] & [-1.0838] \\
\hline \multirow[t]{2}{*}{ Age } & $-0.2088^{\star \star \star}$ & $-0.2444^{\star \star \star}$ & $-0.2234 * \star \star$ & $-0.2824 * \star \star$ \\
\hline & [-7.4311] & {$[-26.1337]$} & {$[-18.7846]$} & {$[-25.1170]$} \\
\hline \multirow[t]{2}{*}{ _cons } & $0.3155^{\star \star \star}$ & $-0.1641^{\star \star \star *}$ & 0.1428 ** & $-0.0683^{* * *}$ \\
\hline & [4.5212] & [-6.8171] & [2.4854] & [-3.1040] \\
\hline$N$ & 243 & 288 & 345 & 546 \\
\hline adj.R-sq & 0.1545 & 0.1475 & 0.0579 & 0.0638 \\
\hline
\end{tabular}

According to Column (2) and (3), there is a negative relationship between tax preference and inefficient investment on the SOEs (with t-statistics ranging from -1.1122 to -1.1058). However, it is not statistically significant. Moving on to Column (4) and (5), we find that the relationship between green tax preference and under-investment levels in Non-SOEs is significantly negative (with t-statistics of -2.1941). This result shows that for every additional unit of green tax preference, the under-investment of Non-SOEs will alleviate $0.0978 \%$. Therefore, among Non-SOEs, the effect of tax preference on the under-investment of renewable energy enterprises is significantly greater than that of SOEs, verifying $\mathrm{H} 2$ and $\mathrm{H} 3$ that green tax incentives will significantly alleviate the under-investment of Non-SOEs more than that of SOEs. As the Non-SOEs share fewer political connections, government funds or subsidies are not always attainable. Tax preferential policies are a vital incentive policy to reduce the financing cost of these constrained companies and mitigate 
under-investment. Senior executives of Non-SOEs are highly sensitive to preferential tax policies and make investment decisions with great caution.

In summary, while green tax preference increases for renewable energy enterprises, under-investment by NonSOEs will be significantly alleviated. Nevertheless, the green tax preference does not have a significant influence on mitigating the under-investment of SOEs. Moreover, whether it is an SOE or a Non-SOE, the green tax preferential policies have no significant influence on the case of over-investment.

\section{Additional robustness checks}

Variable substitution is applied for robustness checks. We replace the explanatory variables in the original text with the natural logarithm of government subsidies and tax incentives, and re-estimate regression model. Firstly, we observe the influence of green fiscal subsidies and tax incentives on inefficient investment of enterprises under the full sample. Then, we study the effects of government subsidies and tax incentives on inefficient investment from the perspective of property heterogeneity. The estimation results of the robustness test are as follows (Table 17, 18, and 19).

The impact of green fiscal policies on the investment efficiency of renewable energy enterprises in the full sample is revealed in Table 17. In column (2) and (3), government subsidy (SUB) is tested as the explanatory variable, and over-investment $(O I)$ and under-investment $(U I)$ are the regression of the explained variables respectively. In column (4) and (5), we test tax incentives (TAX) as the explanatory variable, while overinvestment $(O I)$ and under-investment $(U I)$ are the regressions of the explained variables respectively. When over-investment $(O I)$ was used as the explained variable, the correlation coefficient between government subsidies and over-investment was positive (0.0035) and significant (t-statistic of 1.9219). The results suggest that as government subsidies increase, the problem of over-investment in renewable energy companies will become more serious. However, there was no statistical significance between tax incentives and over-investment (t-statistic of -0.1831). When under-investment $(U I)$ is used as the explained variable, the correlation coefficient between government subsidies and under-investment is negative and not statistically significant (t-statistic is -1.3312), while the correlation coefficient between tax incentives and underinvestment is significantly negative (coefficient is -0.0018 , $t$-statistic of -2.1015 ). The results show that the increase of tax incentives significantly alleviates the problem of insufficient investment in renewable energy enterprises. 
Table 17

Regression results of two green fiscal policies on inefficient investment of enterprises under the total sample

\begin{tabular}{|c|c|c|c|c|}
\hline Variable & 이 & UI & Ol & Ul \\
\hline \multirow[t]{2}{*}{ SUB } & $0.0035^{*}$ & -0.0012 & & \\
\hline & [1.9219] & {$[-1.3312]$} & & \\
\hline \multirow[t]{2}{*}{ TAX } & & & -0.0002 & -0.0018 ** \\
\hline & & & {$[-0.1831]$} & [-2.1015] \\
\hline \multirow[t]{2}{*}{ Size } & $0.0129 * * \star$ & -0.0008 & $0.0117 * \star \star$ & -0.0037 \\
\hline & [10.1820] & {$[-0.3458]$} & [8.0722] & [-1.6325] \\
\hline \multirow[t]{2}{*}{ Roa } & $-0.0341^{\star *}$ & -0.0298 & $-0.0335^{\star \star}$ & -0.0359 \\
\hline & [-2.1032] & [-1.3279] & [-2.0610] & [-1.5952] \\
\hline \multirow[t]{2}{*}{ Oper } & $-0.0086^{\star \star \star *}$ & $-0.0092^{\star \star}$ & $-0.0081^{\star \star \star *}$ & $-0.0115^{\star \star \star}$ \\
\hline & {$[-3.0260]$} & [-2.4388] & [-2.8582] & [-2.9454] \\
\hline \multirow[t]{2}{*}{ ADM } & $0.0184 * \star$ & $0.0460 * \star$ & $0.0179 * \star$ & $0.0551 * \star \star$ \\
\hline & [2.1440] & [2.2983] & [2.0819] & [2.7297] \\
\hline \multirow[t]{2}{*}{ FCF } & $0.0521^{\star \star \star}$ & $-0.0688 * \star \star$ & $0.0496 * \star \star$ & $-0.0681 * \star \star *$ \\
\hline & [3.0112] & [-2.8407] & [2.8642] & [-2.8229] \\
\hline \multirow[t]{2}{*}{ Age } & $-0.2145^{\star \star \star}$ & $-0.2584^{\star \star \star}$ & $-0.2152^{\star \star \star}$ & -0.2564 *** \\
\hline & [-20.3109] & [-37.1235] & [-20.2702] & [-36.7073] \\
\hline \multirow[t]{2}{*}{ _cons } & $0.1686^{\star * \star}$ & $-0.0955^{\star \star \star}$ & $0.1608^{* * *}$ & $-0.0937 * \star \star *$ \\
\hline & [4.0580] & {$[-5.6639]$} & [3.9256] & [-5.6841] \\
\hline$N$ & 588 & 834 & 588 & 834 \\
\hline adj.R-sq & 0.0713 & 0.0655 & 0.0694 & 0.0660 \\
\hline
\end{tabular}

In general, subsidies will aggravate over-investment for renewable energy enterprises significantly, which verifies $\mathrm{H} 1$ that green financial subsidies could significantly increase over-investment. Tax preference will significantly alleviate the phenomenon of corporate under-investment, which verified $\mathrm{H} 2$.

Next, we divide renewable energy enterprises into SOEs and Non-SOEs according to their different ownerships. The original explanatory variable is replaced by the natural logarithm of financial subsidies and tax incentives, and the results are shown in Table 18 and 19. Table 18 reveals the influence of government subsidies on enterprises' inefficient investment under different ownerships. The results are consistent with our previous conclusions. We test government subsidy (SUB) as the explanatory variable, and take over- 
investment (OI) and under-investment ( $(U)$ as the explained variables respectively. In columns (2) and (3), we examine the regression on the investment efficiency of SOEs. In columns (4) and (5), non-state-owned renewable energy enterprises are analyzed. When over-investment $(O)$ was used as the explained variable, the correlation coefficients between government subsidy and over-investment were positive ( 0.0088 and 0.0042 ) and significant (t-statistic of 2.2627 and 2.1324) in both state-owned and non-state-owned enterprises. This indicates that with the increase of government subsidies, both SOEs and Non-SOEs will significantly increase the over-investment level of renewable energy enterprises. In addition, the coefficient of Non-SOEs is lower than that of SOEs $(0.0042<0.0088)$, which shows the influence of government subsidies on the over-investment of renewable energy enterprises is different under the heterogeneity of ownership. There are more serious over-investment on SOEs than that of the Non-SOEs, which verifies our $\mathrm{H} 1$ and $\mathrm{H} 3$. 
Table 18

Regression results of government subsidies on inefficient investment of enterprises under the heterogeneity of ownership

\begin{tabular}{|c|c|c|c|c|}
\hline \multirow[t]{2}{*}{ Variable } & \multicolumn{2}{|l|}{ SOEs } & \multicolumn{2}{|l|}{ Non-SOEs } \\
\hline & 이 & UI & Ol & UI \\
\hline \multirow[t]{2}{*}{ SUB } & $0.0088 * *$ & -0.0078 & $0.0042 *$ & -0.0035 \\
\hline & [2.2627] & {$[-1.5471]$} & [2.1324] & [-1.3289] \\
\hline \multirow[t]{2}{*}{ Size } & $0.0165^{\star \star}$ & -0.0121 *ᄎ* & 0.0028 & -0.0141 *** \\
\hline & [2.6274] & [-7.5595] & [1.0733] & [-6.3665] \\
\hline \multirow[t]{2}{*}{ Roa } & -0.3258 & $-0.0650 * \star$ & $-0.0279 *$ & $-0.1113^{* \star *}$ \\
\hline & [-1.2248] & [-2.2019] & {$[-1.7444]$} & [-2.9562] \\
\hline \multirow[t]{2}{*}{ Oper } & $-0.0887 * \star \star$ & $-0.0325^{\star \star \star}$ & $-0.0062^{\star \star}$ & 0.0031 \\
\hline & [-3.7785] & {$[-6.0141]$} & {$[-2.1510]$} & [0.5401] \\
\hline \multirow[t]{2}{*}{ ADM } & $0.1995^{\star \star \star}$ & 0.0499 & 0.0105 & $0.0915^{\star \star \star}$ \\
\hline & [3.9108] & [1.5832] & [1.2293] & [3.0081] \\
\hline \multirow[t]{2}{*}{ FCF } & $0.3227 \star \star \star *$ & $-0.0852^{\star \star \star}$ & $0.0377 \star \star$ & -0.0415 \\
\hline & [3.9436] & [-2.8509] & [2.1216] & [-1.0374] \\
\hline \multirow[t]{2}{*}{ Age } & $-0.2072^{\star \star \star}$ & $-0.2457 * \star \star$ & $-0.2241 * \star \star$ & $-0.2818 * \star \star$ \\
\hline & [-7.2756] & {$[-26.1683]$} & [-18.9389] & [-25.2869] \\
\hline \multirow[t]{2}{*}{ _cons } & $0.3173^{\star \star \star}$ & 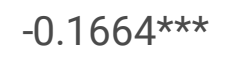 & $0.1528 * \star \star$ & $-0.0719 * * *$ \\
\hline & [4.3490] & [-6.6992] & [2.6844] & [-3.2155] \\
\hline$N$ & 243 & 288 & 345 & 546 \\
\hline adj.R-sq & 0.1546 & 0.1466 & 0.0608 & 0.0624 \\
\hline
\end{tabular}

Table 19 reveals the influence of tax incentives on enterprises' inefficient investment under different ownerships. The results are consistent with our previous conclusions. We test tax incentives (TAX) as the explanatory variable, and take over-investment $(O I)$ and under-investment $(U I)$ as the explained variables respectively. In column (2) and (3), we examine the regression on the investment efficiency of SOEs. In column (4) and (5), non-state-owned renewable energy enterprises are analyzed. When under-investment (UI) is used as the explained variable, the correlation coefficient between tax incentives and under-investment in non-state-owned renewable energy enterprises is negative (-0.0029) and significant (t-statistic is -1.9826). However, it is not statistically significant in state-owned enterprises (t-statistic was -1.0681). This result shows that the impact of tax incentives on the under-investment of renewable energy enterprises is 
significantly different between the samples of SOEs and Non-SOEs, and the alleviating effect of underinvestment of Non-SOEs is significantly greater than that of SOEs, which verifies our $\mathrm{H} 2$ and $\mathrm{H} 3$.

Table 19

Regression results of tax preferences to enterprise inefficient investment under the heterogeneity of ownership

\begin{tabular}{|c|c|c|c|c|}
\hline \multirow[t]{2}{*}{ Variable } & \multicolumn{2}{|l|}{ SOEs } & \multicolumn{2}{|l|}{ Non-SOEs } \\
\hline & 이 & UI & Ol & UI \\
\hline \multirow[t]{2}{*}{ TAX } & -0.0064 & -0.0019 & -0.0012 & $-0.0029 * *$ \\
\hline & [-1.1184] & {$[-1.0681]$} & {$[-1.0510]$} & [-1.9826] \\
\hline \multirow[t]{2}{*}{ Size } & $0.0106^{\star \star \star}$ & -0.0066 & $0.0116 * \star \star$ & $-0.0049 * \star$ \\
\hline & [5.8978] & {$[-1.0614]$} & [4.3577] & [-2.0239] \\
\hline \multirow[t]{2}{*}{ Roa } & -0.2429 & -0.0590 ** & $-0.0265^{\star}$ & -0.1096 *** \\
\hline & [-0.9234] & [-1.9903] & [-1.6486] & [-2.9180] \\
\hline \multirow[t]{2}{*}{ Oper } & $-0.0661^{\star \star *}$ & $-0.0363^{* \star *}$ & $-0.0060 * *$ & 0.0019 \\
\hline & {$[-2.6722]$} & [-6.2961] & [-2.0492] & [0.3290] \\
\hline \multirow[t]{2}{*}{ ADM } & $0.1968 * \star \star *$ & $0.0605^{\star}$ & 0.0102 & $0.0957 * \star \star$ \\
\hline & [4.0011] & [1.9095] & [1.1922] & [3.1495] \\
\hline \multirow[t]{2}{*}{ FCF } & $0.3034^{\star \star \star}$ & $-0.0814^{\star \star \star}$ & $0.0362^{\star \star}$ & -0.0367 \\
\hline & [3.8402] & {$[-2.7418]$} & [2.0296] & {$[-0.9198]$} \\
\hline \multirow[t]{2}{*}{ Age } & $-0.1958^{\star \star \star}$ & $-0.2449 * \star \star *$ & $-0.2239 * \star \star$ & $-0.2745^{\star \star \star}$ \\
\hline & [-6.9246] & {$[-26.1602]$} & {$[-18.8594]$} & [-23.8755] \\
\hline \multirow[t]{2}{*}{ _cons } & $0.3158^{\star \star \star}$ & $-0.1687^{\star \star \star *}$ & $0.1561^{\star \star \star}$ & $-0.0685^{\star \star \star}$ \\
\hline & [4.5769] & [-7.0030] & [2.7164] & [-3.1137] \\
\hline $\mathrm{N}$ & 243 & 288 & 345 & 546 \\
\hline adj.R-sq & 0.1558 & 0.1494 & 0.0504 & 0.0637 \\
\hline
\end{tabular}

The Model designed in this paper has passed the robustness test. The regression results of green financial subsidies and tax incentive policies on inefficient investment of enterprises are the same as our previous regression results, no matter in the case of a full sample or the property heterogeneity.

\section{Conclusions And Policy Implications}


This study focuses on the investment efficiency of renewable energy enterprises and how they respond to green financial subsidies and green tax incentives. Using financial data of 158 renewable energy enterprises for both state-owned (SOEs) and private (Non-SOEs) listed on the Shanghai and Shenzhen Stock Exchange from 2010-2018, we measured the investment efficiency of the renewable energy enterprises with the Richardson model. The fixed-effect panel model was applied to explore the impact of green fiscal policies on the investment efficiency of renewable energy enterprises under the property heterogeneity.

Prior studies suggest that green fiscal policy can affect the investment efficiency of renewable energy enterprises. We extend this research by documenting the varying effects of different green fiscal policies on the enterprises of different ownerships. Our finding is a refinement and extension based on previous research that green financial subsidies aggravate over-investment, especially for SOEs, while green tax incentives alleviate under-investment considerably, especially for the Non-SOEs. Specifically, our results are consistent with hypotheses when tested in several ways. We find inefficient investment pervasive in China, among which over-investment problem is more serious than under-investment, and the under-investment is more observable for the Non-SOEs.

Our findings reflect several implementations for policymakers when it comes to financial subsidies and tax incentives. Investment supervision and financial auditing supervision need to be strengthened to target the tendency of over-investment of SOEs. Besides, strengthening the management of the flow of funds, increasing the number of specialists with financial and technical background in the board of directors will also help SOEs to utilize financial subsidies and make rational investment decisions. To alleviate the underinvestment for Non-SOEs renewable energy enterprises, more preferable policies are advised. Government need to formulate more flexible tax incentives for Non-SOEs, encouraging R\&D innovate and entrepreneurship, and share the investment risks of Non-SOEs. Due to data constraints, this paper cannot provide a comprehensive review of the investment efficiency of renewable energy enterprises. Future research can be improved on the enterprise selection criteria, increasing the number of research samples and improving the accuracy of Richardson model estimation. We leave these issues for future study.

\section{Declarations}

Funding This research is funded by the National Social Science Foundation of China (NO.19BJY151). The National Social Science Foundation of China provided the necessary financial support for the research.

Competing Interests The authors have no relevant financial or non-financial interests to disclose.

Acknowledgements Funding from the National Social Science Foundation of China (NO.19BJY151) is gratefully acknowledged.

Author contribution Zhaosu Meng contributed to the study conception and design. Material preparation, data collection, and analysis were performed by Huike Sun and Xiaotong Liu. The first draft of the manuscript was written by Huike Sun and Xiaotong Liu, and all authors commented on previous versions of the manuscript. All authors read and approved the final manuscript. 
Data availability The datasets used and/or analyzed during the current study are available from the corresponding author on reasonable request.

Ethics approval and consent to participate We declare that we have no human participants, human data, or human issues.

Research involving human participants and/or animals Not applicable.

Consent for publication We give consent for publication in true letter and spirit.

Conflict of interest The authors declare no conflict of interest.

\section{References}

1. Aggarwal RK, Samwick AA (2006) Empire-builders and shirkers: Investment, firm performance, and managerial incentives. J Corp Financ 12:489-515. https://doi.org/10.1016/j.jcorpfin.2006.01.001

2. Aivazian VA, Ge Y, Qiu J (2005) Debt Maturity Structure and Firm Investment. Financ Manage 34:107119

3. Allen F, Qian J, Qian M (2005) Law, finance, and economic growth in China. Financ Econ 77:57-116. https://doi.org/10.1016/j.jfineco.2004.06.010

4. Biddle GC, Hilary G, Verdi RS (2009) How does financial reporting quality relate to investment efficiency? J Account Econ 48:112-131. https://doi.org/10.1016/j.jacceco.2009.09.001

5. Billett MT, Garfinkel JA, Jiang Y (2011) The influence of governance on investment: Evidence from a hazard model. J Financ Econ 102:643-670. https://doi.org/10.1016/j.jfineco.2011.07.004

6. Butler L, Neuhoff K (2008) Comparison of feed-in tariff, quota and auction mechanisms to support wind power development. Renew Energ 33:1854-1867. https://doi.org/10.1016/j.renene.2007.10.008

7. Chang K, Wan Q, Lou Q-C, Chen Y, Wang W-H (2020) Green fiscal policy and firms' investment efficiency: New insights into firm-level panel data from the renewable energy industry in China. Renew Energ 151:589-597. https://doi.org/10.1016/j.renene.2019.11.064

8. Chen S-M, Sun Z, Tang S, Wu D-H (2010) Government intervention and investment efficiency: Evidence from China. J Corp Financ 17(2):259-271. https://doi.org/10.1016/j.jcorpfin.2010.08.004

9. Chien FS, Hsu CC, Zhang Y, Tran TD, Li L (2021) Assessing the impact of green fiscal policies and energy poverty on energy efficiency. Environ Sci Pollut Res Int. https://doi.org/10.1007/s11356-021-15854-7

10. Comello S, Reichelstein S (2016) The U.S. investment tax credit for solar energy: Alternatives to the anticipated 2017 step-down. Renew Sust Energ Rev 55:591-602

11. Fakhfakh H, Zouari G, Zouari-Hadiji R (2012) Internal capital markets and investment decisions. Corp Gov 12(2):179-198

12. Fan J, Wong T, Zhang T (2006) Politically connected CEOs, corporate governance, and Post-IPO performance of China's newly partially privatized firms. J Financ Econ 84(2):330-357. https://doi.org/10.1016/j.jfineco.2006.03.008 
13. Fazzari S, Hubbard R, Petersen B (1988) Investment, financing decisions, and tax policy. Am Econ Rev 78(2):200-205

14. Francisco G (2020) Creditor rights, financial health, and corporate investment efficiency. N Am J Econ Financ 51:100873-100873. https://doi.org/10.1016/j.najef.2018.11.002

15. Gu Beibei and Chen Fang and Zhang Kun (2021) The policy effect of green finance in promoting industrial transformation and upgrading efficiency in China: analysis from the perspective of government regulation and public environmental demands. Environ Sci Pollut Res Int 28(34):4747447491. https://doi.org/10.1007/s11356-021-13944-0

16. Gulen H, Ion M (2015) Policy Uncertainty and Corporate Investment. Rev Financ Stud 29(3):523-564. https://doi.org/10.1093/rfs/hhv050

17. Hottenrott H, Lopes-Bento C (2014) (International) R\&D collaboration and SMEs: The effectiveness of targeted public R\&D support schemes. Res Policy 43:1055-1066.

https://doi.org/10.1016/j.respol.2014.01.004

18. Iuliana $P$ (2008) The influence of the financial factors on cash flow: As determining factor of firm's investment decisions. Economic Science Series 17(3):483487

19. Jensen MC (1986) Agency Costs of Free Cash Flow, Corporate Finance, and Takeovers. Am Econ Rev 76(2):323-329. https://www.jstor.org/stable/1818789

20. Johansson P, Kriström B (2019) Welfare evaluation of subsidies to renewable energy in general equilibrium: Theory and application. Energ Econ 83:144-155.

https://doi.org/10.1016/j.eneco.2019.06.024

21. Karim ZA, Azman-Saini WNW (2013) Firm-level investment and monetary policy in Malaysia: do the interest rate and broad credit channels matter? J Asia Pac Econ 18:396-412. https://doi.org/10.1080/13547860.2012.742686

22. Kwon C, Zhang G, Zhou H (2020) Monetary policy, social capital, and corporate investment. J Econ Financ 44:1-34. https://doi.org/10.1007/s12197-019-9469-y

23. Liang B-M, Zhang F-Y (2019) Has Government Subsidy Affected the Investment Efficiency of Listed Companies? Contemporary Economic Research 06:95-104 (in Chinese)

24. Liu J, Gong E, Wang X (2021) Economic benefits of construction waste recycling enterprises under tax incentive policies. Environ Sci Pollut Res Int. https://doi.org/10.1007/s11356-021-13831-8

25. Lokshin B, Mohnen $P$ (2012) How effective are level-based R\&D tax credits? Evidence from the Netherlands. Appl Econ 44(12):1527-1538. https://doi.org/10.1080/00036846.2010.543083

26. Meckling W, Jensen M (1976) Theory of the firm: Managerial behavior, agency costs and ownership structure. J Financ Econ 3(4):305-360. https://doi.org/10.1016/0304-405X(76)90026-X

27. Mohammed A, Ahmed A, Grantley T, Lien D (2020) Is corporate tax avoidance associated with investment efficiency? N Am J Econ Financ 52:101143-101143. https://doi.org/10.1016/j.najef.2020.101143

28. Morgado A, Pindado J (2003) The Underinvestment and Overinvestment Hypotheses: an Analysis Using Panel Data. Eur Financ Manag 9:163-177. https://doi.org/10.1111/1468-036X.00214 
29. Mundaca G (2017) Energy subsidies, public investment and endogenous growth. Energy Policy 110:693-709. https://doi.org/10.1016/j.enpol.2017.08.049

30. Newell RG, Pizer WA, Raimi D (2019) U.S. federal government subsidies for clean energy: Design choices and implications. Energ Econ 80:831-841. https://doi.org/10.1016/j.eneco.2019.02.018

31. Nie P-Y, Chen Y-H, Yang Y-C, Wang XH (2016) Subsidies in carbon finance for promoting renewable energy development. J Clean Prod 139:677-684

32. O'Toole CM, Morgenroth ELW, Ha TT (2016) Investment efficiency, state-owned enterprises and privatisation: Evidence from Viet Nam in Transition. J Corp Financ 37:93-108

33. Ozorhon B, Batmaz A, Caglayan S (2018) Generating a framework to facilitate decision making in renewable energy investments. Renew Sust Energ Rev 95:217-226. https://doi.org/10.1016/j.rser.2018.07.035

34. Peng BH, Yan WM, Elahi E, Wan AX (2022) Does the green credit policy affect the scale of corporate debt financing? Evidence from listed companies in heavy pollution industries in China. Environ Sci Pollut Res Int 29:755-767. https://doi.org/10.1007/s11356-021-15587-7

35. Richardson S (2006) Over-investment of free cash flow. Rev Account Stud 11:159-189. https://doi.org/10.1007/s11142-006-9012-1

36. Singarao VY, Singh RP, National Renewable Energy Policies (2014) Review of State and. 2014 Sixth Annual IEEE Green Technologies Conference. IEEE: 81-86 https://www.webofscience.com/wos/alldb/full-record/WOS:000356239700017

37. Tullock G (1967) The welfare costs of tariffs, monopolies, and theft. Econ Inq 5(3):224232. https://doi.org/10.1111/j.1465-7295.1967.tb01923.x

38. Vogt $S$ et al (1994) HIRES: the high-resolution echelle spectrometer on the Keck 10-m Telescope. Phys A 2198:362375. https://doi.org/10.1117/12.176725

39. Wang Y-Z, Chen L-F, Huang YS, Li Y (2018) How does credit market distortion affect corporate investment efficiency? The role of managerial forecast. Financ Res Lett 25:266-273. https://doi.org/10.1016/j.frl.2017.11.004

40. Xiao M (2010) Cash Dividend, Internal Cash Flow and Investment Efficiency. J Financ Res 10:117-134 (in Chinese)

41. Yang X-L, He L-U, Xia Y-F, Chen Y-F (2019) Effect of government subsidies on renewable energy investments: The threshold effect. Energy Policy 132:156-166. https://doi.org/10.1016/j.enpol.2019.05.039

42. Yu W-C, Liang P-H, Gao N (2021) Can higher levels of disclosure bring greater efficiency: Empirical research on the effect of government information disclosure on enterprise investment efficiency. China Econ Q Int 1:221-232. https://doi.org/10.1016/j.ceqi.2021.09.001

43. Zhang H-M, Li L-S, Zhou D-Q, Zhou P (2014) Political connections, government subsidies and firm financial performance: Evidence from renewable energy manufacturing in China. Renew Energ 63:330336. https://doi.org/10.1016/j.renene.2013.09.029

44. Zhu Z-H, Zhu Z-W, Xu P, Xue D-W (2019) Exploring the impact of government subsidy and R\&D investment on financial competitiveness of China's new energy listed companies: An empirical study. 
Energy Rep 5:919-925. https://doi.org/10.1016/j.egyr.2019.07.013

45. Zulkhibri M (2015) Interest burden and external finance choices in emerging markets: Firm-level data evidence from Malaysia. Int Econ 141:15-33. https://doi.org/10.1016/j.inteco.2014.11.002

\section{Figures}

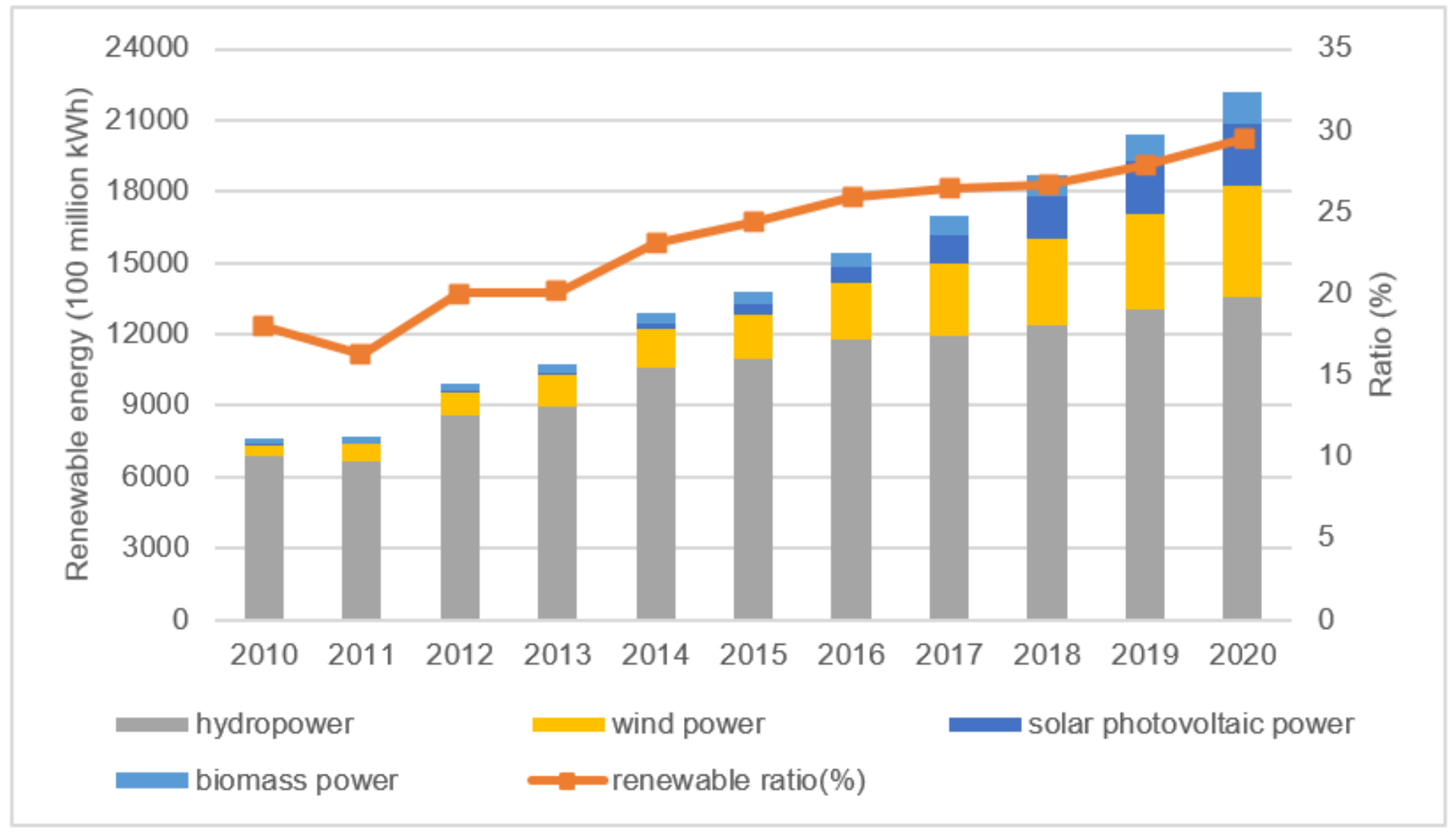

Figure 1

China's renewable energy production from 2010 to 2020 


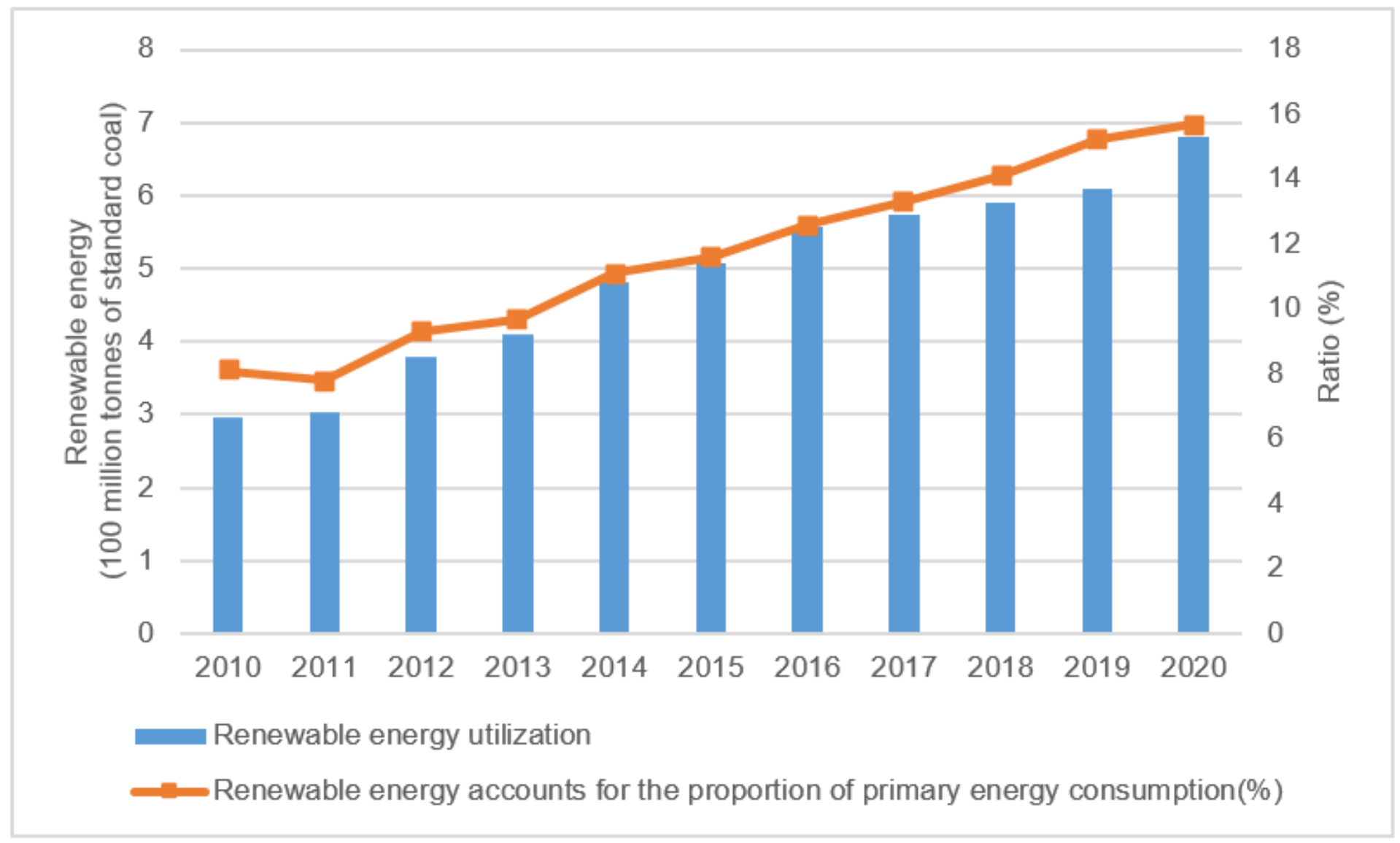

Figure 2

China's renewable energy utilization from 2010 to 2020 


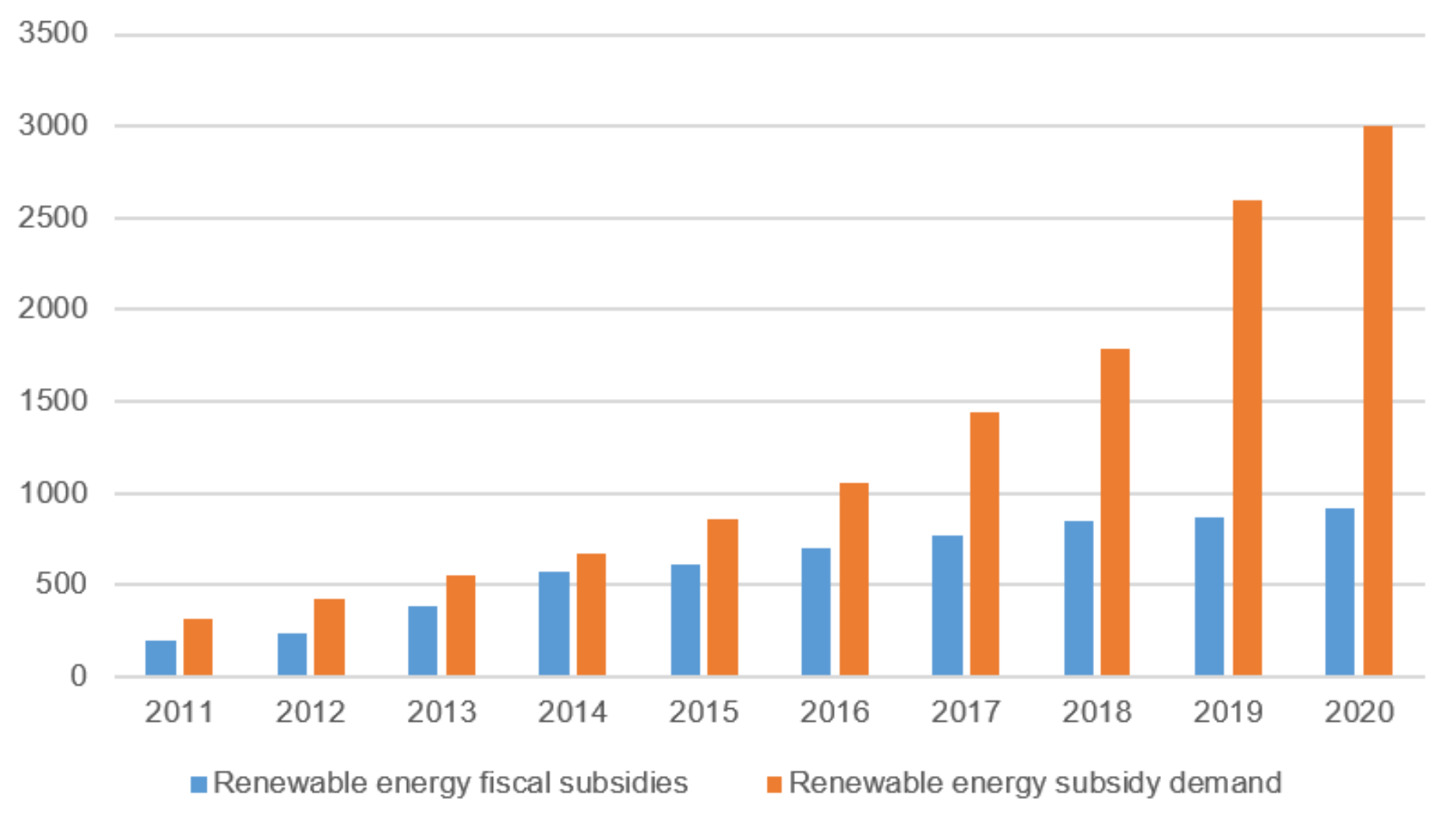

\section{Figure 3}

The demand for renewable energy subsidies and the total amount of financial subsidies from 2011 to 2020 (billion RMB) 